US Army Corps

of Engineers ${ }_{\circledast}$

Engineer Research and

Development Center

Ecosystem Management and Restoration Research Program (EMRRP)

\title{
Watershed Level Effects of Multiple Ecosystem Restoration Projects
}

Christy M. Foran, Cate Fox-Lent, Colin Chadderton,

Wendy Gendron, Lawrence Oliver, Eivy Monroy, James Turek, Phillip Edwards, and Burton Suedel 
The U.S. Army Engineer Research and Development Center (ERDC) solves the nation's toughest engineering and environmental challenges. ERDC develops innovative solutions in civil and military engineering, geospatial sciences, water resources, and environmental sciences for the Army, the Department of Defense, civilian agencies, and our nation's public good. Find out more at www.erdc.usace.army.mil.

To search for other technical reports published by ERDC, visit the ERDC online library at http://acwc.sdp.sirsi.net/client/default. 


\section{Watershed Level Effects of Multiple Ecosystem Restoration Projects}

Christy M. Foran, Cate Fox-Lent, and Colin Chadderton

U.S. Army Engineer Research and Development Center (ERDC)

Environmental Laboratory

696 Virginia $R d$

Concord, MA 01742

Wendy Gendron, and Lawrence Oliver

U.S. Army Corps of Engineers

New England District

696 Virginia $R d$

Concord, MA 01742

Eivy Monroy

Narragansett Bay Estuary Program

235 Promenade Street, Suite 310

Providence, RI 02908
James Turek

National Oceanic and Atmospheric Administration

National Marine Fisheries Service

Restoration Center

28 Tarzwell Drive

Narragansett, RI 02882

Phillip Edwards

Rhode Island Department of Environmental

Management

235 Promenade Street

Providence, RI 02908

Burton Suedel

U.S. Army Engineer Research and Development Center (ERDC)

Environmental Laboratory

3909 Halls Ferry Road

Vicksburg, MS 39180

Final Report

Approved for public release; distribution is unlimited.

Prepared for Headquarters, U.S. Army Corps of Engineers

Washington, DC 20314-1000

Under Watershed Level Effects of Multiple Ecosystem Restoration Projects \# 468903 


\section{Abstract}

This assessment in the Narragansett Bay demonstrates a transparent, defensible method to characterize ecosystem restoration projects in a watershed over large spatial scales. The project team compiled multiple completed projects in the Narragansett Bay watershed including salt marsh restorations, fish passage, and dam removals. The approach included the following: identifying and locating restoration projects, utilizing existing data resources for spatial information, quantifying the gains in area and distance, and extrapolating the potential for collective watershed benefit in fish populations, productivity, water quality and carbon sequestration. In total, 177 projects were identified as being implemented between 1999 and 2015: fish passage restoration (46), marsh restoration (35), eel grass restoration (22), shellfish restoration (43), and other projects (31). The collective efforts to improve fish passage have resulted in more than $800 \mathrm{~km}$ of newly accessible river herring habitat in the Narragansett Bay watershed.

DISCLAIMER: The contents of this report are not to be used for advertising, publication, or promotional purposes. Citation of trade names does not constitute an official endorsement or approval of the use of such commercial products. All product names and trademarks cited are the property of their respective owners. The findings of this report are not to be construed as an official Department of the Army position unless so designated by other authorized documents. 


\section{Contents}

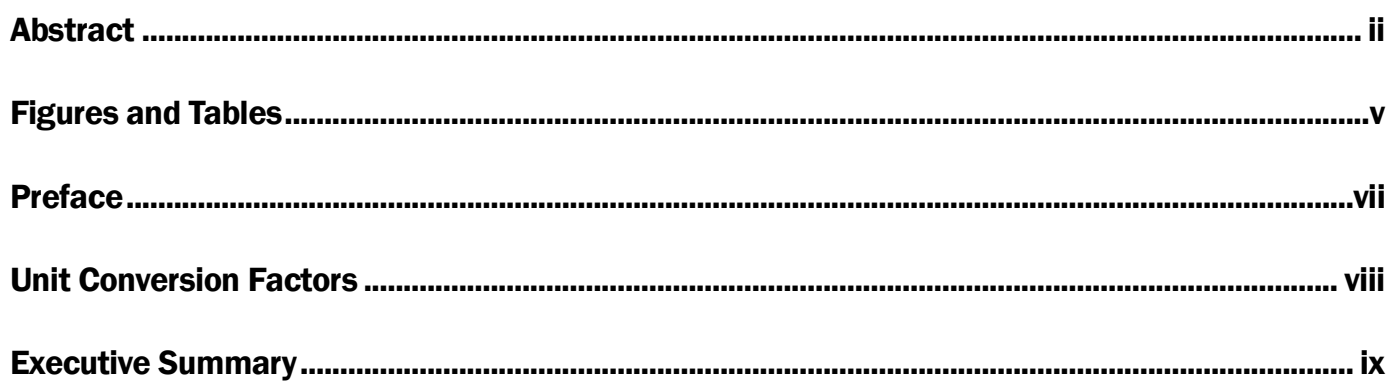

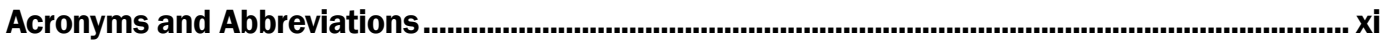

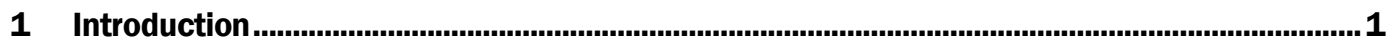

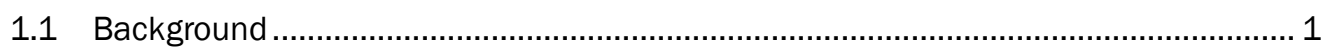

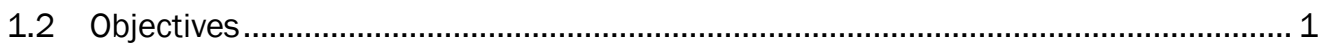

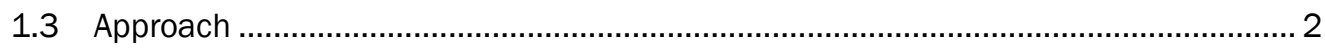

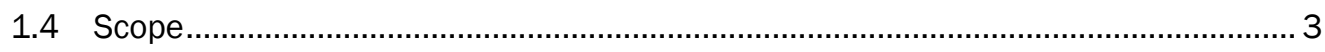

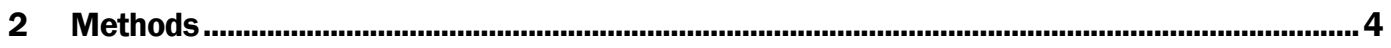

2.1 Data collection and validation ....................................................................... 4

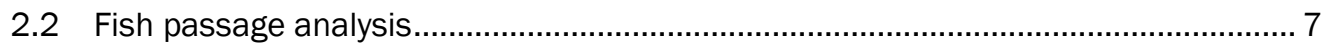

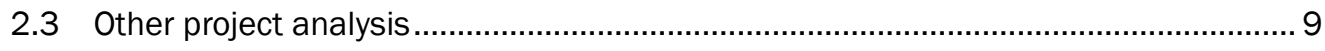

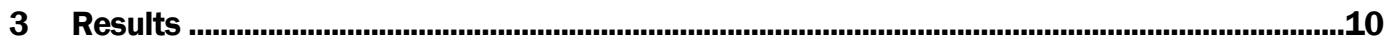

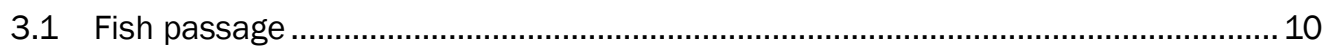

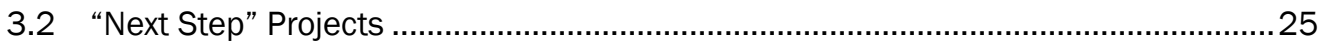

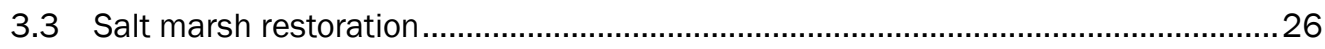

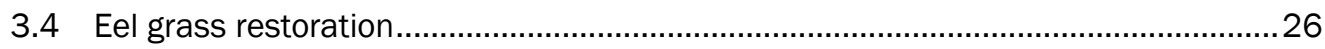

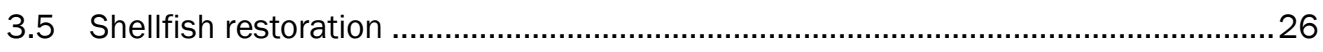

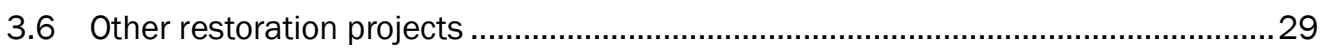

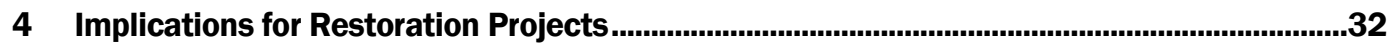

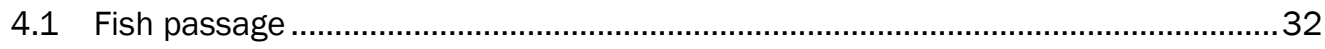

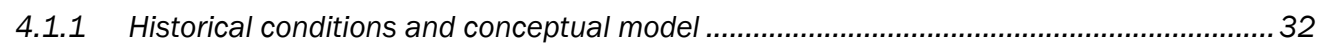

4.1.2 Restoration calculations and accomplishments ........................................................ 33

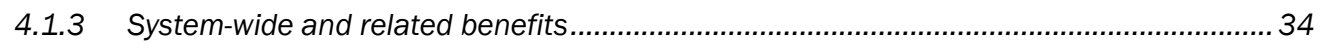

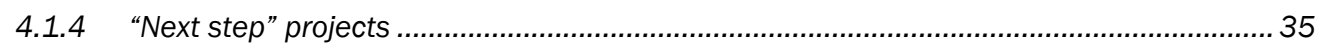

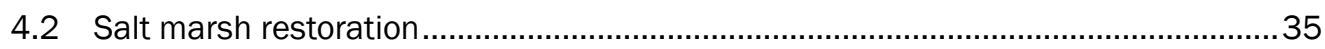

4.2.1 Historical Conditions and Conceptual Model ................................................................ 35

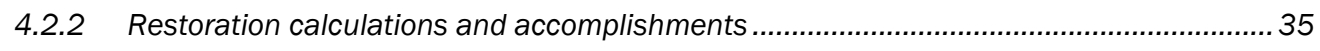

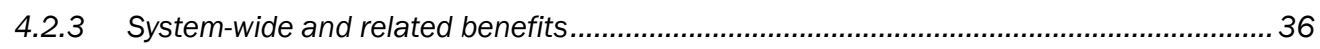

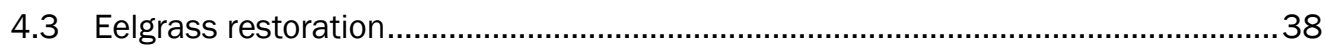

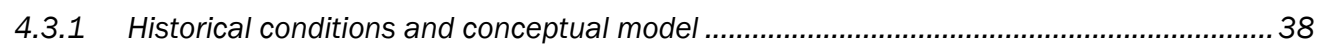

4.3.2 Restoration calculations and accomplishments .......................................................... 38

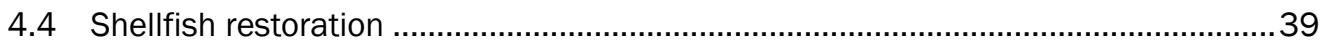


4.4.1 Historical conditions and conceptual model ................................................................... 39

4.4.2 Restoration calculations and accomplishments ............................................................ 40

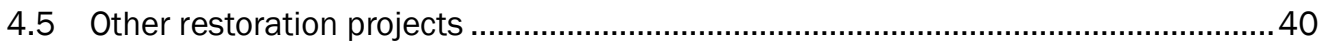

5 Discussion ...............................................................................................................................41

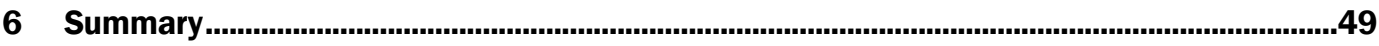

References ...............................................................................................................................................50

Report Documentation Page 


\section{Figures and Tables}

\section{Figures}

Figure 1. Map of southeastern New England highlighting (red) the Narragansett Bay watershed study boundary...

Figure 2. Diagram describing how the river lengths associated with restoration for various species were identified

Figure 3. Dam passability, river access, and lake access opened in the Upper Narragansett watershed through the collective implementation of Narragansett Bay restoration projects. The displayed watersheds are the HUC-12 that drain into the Upper Bay.

Figure 4. Dam passability, river access, and lake access opened in the Upper Narragansett watershed through the collective implementation of Narragansett Bay restoration projects. The displayed watersheds are the HUC-12 that drain into the Upper Bay.

Figure 5. Dam passability, river access, and lake access opened in the Pawtuxet watershed through the collective implementation of Narragansett Bay restoration projects.

Figure 6. Dam passability, river access, and lake access opened in the Ten Mile watershed through the collective implementation of Narragansett Bay restoration projects.

Figure 7. Dam passability, river access, and lake access opened in the Palmer watershed through the collective implementation of Narragansett Bay restoration projects.

Figure 8. Dam passability, river access, and lake access opened in the Taunton watershed through the collective implementation of Narragansett Bay restoration projects.

Figure 9. Dam passability, river access, and lake access opened in the Sakonnet watershed through the collective implementation of Narragansett Bay restoration projects.

Figure 10. Dam passability, river access, and lake access opened in the Lower West Passage watershed through the collective implementation of Narragansett Bay restoration projects.

Figure 11. Dam passability, river access, and lake access opened in the Pettaquamscutt watershed through the collective implementation of Narragansett Bay restoration projects.

Figure 12. Dam passability, river access, and lake access opened in the Hunt watershed through the collective implementation of Narragansett Bay restoration projects.

Figure 13. Map of Narragansett Bay marsh restoration projects in the study area shown with approximate existing wetland areas from the National Wetlands Inventory V2, and degraded coastal wetlands delineated from 1996 aerial photography.

Figure 14. Map of Narragansett Bay eelgrass restoration projects in the study area.

Figure 15. Map of Narragansett Bay shellfish projects. Note that the colors represent different shellfish targets for the projects. Purple circles are for clams. Red circles are for lobster. Orange circles are for oysters. Green circles are for scallops. The remaining project (pink) was reported generally as shellfish enhancement.

Figure 16. Map of Narragansett Bay other restoration projects. The dark green circles are projects described as habitat restoration. The light green circles show the location of shoreline restoration projects. 
Figure 17. Conceptual model for consideration of restoration projects. The first network (far left) is a representation of the historical sites, and extent and interactions of fish habitat. Shading in that network represents the current (darker) and currently possible (lighter) extent of the habitat given the encroachment of development. From the current conditions (second from left), restoration adds back sites and connectivity that pushes the system toward the maximum possible given current conditions (far right)

Figure 18. Conceptual interactions between the types of restoration projects. Likely interactions between fish passage and salt marsh projects (1) are creation of shelter and productive feeding area for hatched fish on their way back to the bay. Between fish passage and shellfish restoration (2) interactions are water quality, water filtration, and prey availability. Fish passage project and eelgrass restoration (3) are linked through the juvenile fish habitat in the estuary. Salt marsh restoration and shellfish projects (4) interact through retention of sediments and nutrients and improved water quality, and physical support of marsh grass. Salt marshes and shellfish restoration (5) are both dependent on water quality. Eel grass and salt marsh restoration (6) both provide additional shelter for small animals and recruitment for larvae.

\section{Tables}

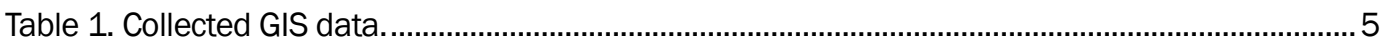

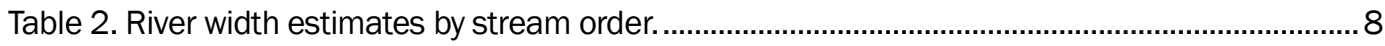

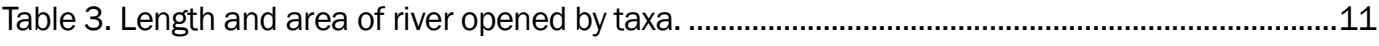

Table 4. Next step projects for dam removal or fish passage addition.................................................25

Table 5. Estimated carbon emissions, based on categorization. .........................................................37 


\section{Preface}

This study was developed to identify and document ecosystem restoration efforts in the Narragansett Bay since 1999. Publication of this report was sponsored by the Ecosystem Management and Restoration Research Program (EMRRP) Work Unit \#468903. Dr. Trudy Estes was the Program Manager and Dr. Alfred Cofrancesco was the Technical Director.

This report was prepared by the Engineer Research and Development Center - Environmental Laboratory (ERDC-EL), Vicksburg, MS. The research was conducted by the Environmental Risk Assessment Branch-of the Environmental Laboratory (ERAB - EL).

This report was written under the direct supervision of Mr. Warren Lorentz, Chief, Environmental Processes and Engineering Division, Dr. Bill Nelson, Chief, Environmental Risk Assessment Branch, EL, and Dr. Ilker R. Adiguzel, Director, EL.

The authors thank Mr. Mike Scuderi, U.S. Army Corps of Engineers (USACE) Seattle District, and Mr. Kyle McKay, ERDC-EL, for reviewing this report.

COL Ivan P. Beckman was Commander of ERDC, and Dr. David W. Pittman was the Director. 


\section{Unit Conversion Factors}

\begin{tabular}{|l|l|l|}
\hline Multiply & By & To Obtain \\
\hline cubic inches & $1.6387064 \mathrm{E}-05$ & cubic meters \\
\hline cubic yards & 0.7645549 & cubic meters \\
\hline feet & 0.3048 & meters \\
\hline foot-pounds force & 1.355818 & joules \\
\hline hectares & $1.0 \mathrm{E}+04$ & square meters \\
\hline inches & 0.0254 & meters \\
\hline inch-pounds (force) & 0.1129848 & newton meters \\
\hline kilotons (nuclear equivalent of TNT) & 4.184 & terajoules \\
\hline miles (nautical) & 1,852 & meters \\
\hline miles (U.S. statute) & $1,609.347$ & meters \\
\hline yards & 0.9144 & meters \\
\hline
\end{tabular}




\section{Executive Summary}

U.S. Army Corps of Engineers (USACE) Districts and other agencies have completed multiple ecosystem restoration projects throughout the United States, however, the benefits of such discrete projects can be understated if not presented in a broader context. There is a perceived benefit to watershed studies because of a perception that there is greater benefit to linking projects at the watershed level. An assessment of the cumulative and interrelated effects of multiple ecosystem restoration projects could quantify and demonstrate the added function and value provided by completed and future projects (i.e., a post-project cumulative assessment at the watershed scale).

This report documents restoration projects in the Narragansett Bay watershed, working in collaboration with state and regional experts, nongovernmental organizations, and Federal partners to identify and mine available data and other information. Projects targeted for evaluation in the approach included fish passage, dam removal, and estuary restoration projects completed from 1999 to 2016. The compilation identified 163 completed projects within the designated project area, including 58 fish passage projects, 39 marsh restoration projects, 17 eelgrass restoration projects, 21 shellfish restoration projects, and 28 "other" projects (primarily shoreline stabilization). The primary justifications for the projects range from benefiting a specific species to restoration of hydrologic processes such as tidal flushing.

The identified projects are designed to restore specific ecosystem attributes and result in gains in ecological function of the Narragansett Bay watershed. Considering the historic and current amount of the restored habitat in the study area, this framework allows the visualization of the incremental contribution of the restoration project. Improved fish passage has resulted in hundreds of kilometers of newly accessible aquatic and riverine habitat for alewife and blueback herring, American shad, and American eel. Marsh and eelgrass restoration provides benefits in the broad categories of biological productivity, species abundance and diversity, water quality, and carbon sequestration. In addition to the habitat benefits of eelgrass, eelgrass beds dampen wave energy, stabilize sediments, and filter nutrients in water column. The benefits of shellfish efforts are cyclical and dependent on water quality, oxygen levels at the sea floor and the amount of silt and sediment coming into the area. The other 
restoration projects evaluated can be broadly classified targeting shoreline protection, drainage enhancement or habitat improvement.

However, there are still many unanswered questions, especially regarding the potential interactions of these projects. The interconnections among species that use very different habitats at a watershed scale have not been well quantified. For instance, anadromous river herring passage projects produce populations of river herring that are connected to riverine habitats by their spawning requirements and to restored salt marshes by their need for cover on their outmigration to the bay and ocean. They also benefit from restored freshwater marshes that provide cover for juvenile fish. The additional fish produced by salt marshes can also be difficult to enumerate. The direct benefits estimated here are largely based on simple population densities and utilizing the created, or opened, habitat area. 


\section{Acronyms and Abbreviations}

CFR Coldwater Fisheries Resources

CRMC Coastal Resources Management Council

DEP Department of Environmental Protection

DoD Department of Defense

EBI Estuarine Biologic Index

EBTJV Eastern Brook Trout Joint Venture

EL Environmental Laboratory

EMRRP Ecosystem Management and Restoration Research Program

ERAB Environmental Risk Assessment Branch

ERDC Engineer Research Development Center

GIS Geographic Information Systems

ha Hectares

HGM Hydrogeomorphic models

IBI Index of Biological Integrity

IWQMA Integrated Water Quality Monitoring and Assessment

$\mathrm{km} \quad$ Kilometers

L Liters

MADER Massachusetts Division of Ecological Restoration

MADFW Massachusetts Division of Fisheries and Wildlife

MAWI Multi-scale Assessment of Watershed Impacts

MTCO2e Metric Tons of Carbon Dioxide Equivalents

$\mathrm{N} \quad$ Nitrogen

NBEP Narragansett Bay Estuary Program

NHD National Hydrology Database

NOAA RC National Oceanographic and Atmospheric Administration's

Restoration Center

OHI Ocean Health Index

RIDEM Rhode Island Department of Environmental Management 


$\begin{array}{ll}\text { SMEs } & \text { Subject Matter Experts } \\ \text { USACE } & \text { U.S. Army Corps of Engineers } \\ \text { USFWS } & \text { U.S. Fish and Wildlife Service } \\ \text { USGS } & \text { U.S. Geological Survey } \\ \text { WCP } & \text { Wetlands Conservancy Program }\end{array}$




\section{Introduction}

\subsection{Background}

The United States Army Corps of Engineers (USACE) districts and other local, state, and Federal agencies and parties have completed numerous ecosystem restoration projects throughout the United States (Bernhardt et al. 2005). The degree to which these projects and surrounding habitats within a watershed benefit from other projects has not been documented. There is a perceived synergistic benefit to watershed studies that consider all potential restoration opportunities in a watershed because of an expectation that there is greater benefit to linking projects at the watershed level. However, project sponsors often have a narrow focus on restoration at a specific site, and often for a specific purpose (e.g., fisheries, water quality), and often do not have the financial capability to undertake more comprehensive watershed-scale studies. This may result in a less systematic approach to restoration project implementation. When viewed at the watershed scale, the projects have nonetheless resulted in greater realized benefits at larger scales whether they are implemented as a result of a watershed study, or as individual discrete actions. This assessment of the cumulative, interrelated effects of multiple ecosystem restoration projects conducted quantifies and demonstrates the added function and value provided by completed and future projects when considered as a whole (i.e., a post-project cumulative benefits assessment at the watershed scale).

\subsection{Objectives}

The objective of this demonstration project was to examine multiple completed projects in the Narragansett Bay watershed to visualize and quantify the relationship among projects and the surrounding ecosystems. The assessment demonstrates the potential cumulative benefits of the restoration investments since 1999 . Because of the continuous restoration work being performed in this watershed, this analysis can be considered a snapshot in time, as discrete projects are ongoing that aim to restore the watershed. This project demonstrates a simple proof-of-concept methodology to quantify the cumulative value of discrete aquatic ecosystem restoration projects on the improvement in ecosystem services and function at a watershed scale. The benefits of ecosystem restoration 
projects completed by the restoration community in Narragansett Bay, Rhode Island (RI) and Massachusetts (MA) were assessed including salt marsh restorations and fish passage.

\subsection{Approach}

Restoration work in Narragansett Bay and its watershed was expected to have a range of benefits as reported in the project documents compiled and reviewed for the present study (Figure 1). Prevalent among these were increasing fish passage to increase the populations of anadromous fishes, increasing marsh area to enhance species diversity and restore scarce and valuable coastal habitats, promoting shellfish recruitment, and increasing survival and areal extent of eelgrass. In fact, gains in the local populations of alewife and herring are attributed in part to completed fish passage projects (Sheppard and Block 2013). Salt marsh restoration leads to in improvements in water quality and nekton populations. Eelgrass restoration efforts have improved the understanding of the effect of water quality, water depth, and invasive herbivores on the stability of eelgrass transplants. Shellfish seeding, along with measurements of their survival and recruitment, have informed changes in designated sanctuaries. Collectively, restoration efforts have produced demonstrable benefits in Narragansett Bay, but to date no research has been conducted to quantify these benefits on a watershed scale.

Fish passage projects in the watershed include dam removal, culvert replacements, and a variety of fish ladders including Denil, Alaskan steeppass, pool and weir, and natural rock ramps. In some locations, separate eel ramps are also included. Dam removal and fishway construction projects were considered relative to impassable obstructions in the major rivers and tributaries of the Narragansett Bay watershed. Analysis of flowlines (streams and rivers) from the estuary to the first unpassable obstruction allowed the calculation of additional river length that has now been opened up to fish passage in general, and the habitat access acres opened for each of five target aquatic species. New riverine habitat for fish species was defined by the length of the river and its tributaries opened to the species. Subsequently, opportunities were identified to leverage these projects for further gain. Noted as "next steps" projects, dam construction of fish passage would open up significant area upstream of the dam, or where observed use of the fishway was low and additional species support could realize substantial improvements. 
Figure 1. Map of southeastern New England highlighting (red) the Narragansett Bay watershed study boundary.

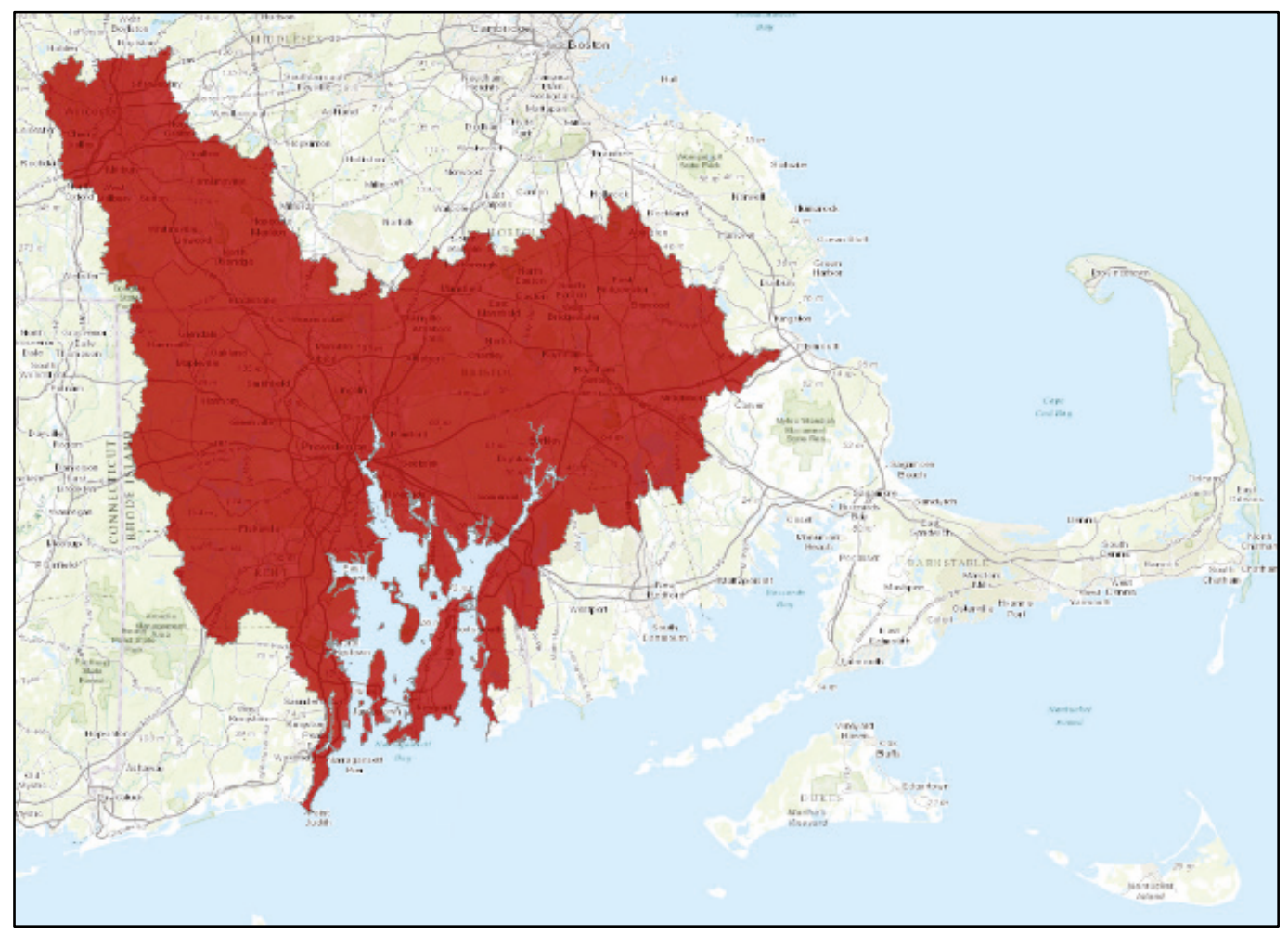

The locations of salt marsh, shellfish, eelgrass, and other restoration projects in the Narragansett Bay were mapped, along with additional information such as project size or footprint and the stated purpose of the projects. The collective size attributed to these projects was described in the context of the historical and current amounts of resources in the study region. For each group of restoration projects, an estimate was made of the implications of those activities for regional restoration based on case studies or accounts from relevant literature. Further analysis demonstrated how additional benefits can be calculated, including expected change in fish and shellfish populations and expected carbon sequestration at restoration project sites.

\subsection{Scope}

This project developed a simple means for assessing the cumulative benefits of aquatic ecosystem restoration projects of USACE and other parties that can be used to document the improvement in ecosystem services and function at a watershed scale. The team assessed the multiple benefits of aquatic restoration projects in Narragansett Bay including salt marsh restorations, fish passage (in conjunction with ongoing maintenance dredging), and permitting of general and individual projects). 


\section{Methods}

\subsection{Data collection and validation}

Restoration project information was compiled from a variety of sources. The USACE, the Narragansett Bay Estuary Program (NBEP), the National Oceanographic and Atmospheric Administration's Restoration Center (NOAA RC), and the RI Coastal Resources Management Council (CRMC) provided restoration project data dating to 1997. The USACE provided information on eight projects and a set of permits issued for marsh restoration projects in the study area. The NBEP provided information on fish passage previously collected from other sources. The NOAA RC provided annual records of any projects that received funding from 2006 to 2016. The CRMC provided a list of 202 projects with associated points of contact, and a project conclusion report associated with 16 habitat restoration projects. This initial compilation provided the majority of the projects included in the analysis. A decision was made to focus on restoration projects, and not include that body of work for the purpose of mitigation.

Additional details and clarifications on these projects were provided by project leaders and other subject matter experts (SMEs) familiar with restoration efforts in Narragansett Bay, much of which focused on fish passage. Local fish passage experts resolved conflicting information about dam status, location, target species, fish passage type, and passability to anadromous fish species and catadromous (American eel) fish. ${ }^{1,2}$ Generally, fish passage has be used here as a term to indicate passage for anadromous species of herring and shad while eel passage indicates ramps allowing catadromous movement around blockages. Geographic information systems (GIS) data for the spatial analysis were also collected and compiled (Table 1).

\footnotetext{
1 Phillip Edwards; Rhode Island Department of Environmental Management; pers. comm; May/2016

2 Brad Chase, Massachusetts Division of Marine Fisheries; pers. comm; May/2016
} 
Table 1. Collected GIS data.

\begin{tabular}{|c|c|c|}
\hline Dataset & Source & Access \\
\hline $\begin{array}{l}\text { Narragansett Bay Study } \\
\text { Area (polygon) }\end{array}$ & $\begin{array}{l}\text { Narragansett Bay Estuary } \\
\text { Program (NEBP) }\end{array}$ & Personal communication*, NBEP \\
\hline Dam locations (point) & $\begin{array}{l}\text { Rhode Island Department of } \\
\text { Environmental Management } \\
\text { (RIDEM) }\end{array}$ & Personal communication*, NBEP \\
\hline Dam locations (point) & $\begin{array}{l}\text { Massachusetts Division of } \\
\text { Ecological Restoration } \\
\text { (MADER) }\end{array}$ & Personal communication*, NBEP \\
\hline Dam locations (point) & $\begin{array}{l}\text { Massachusetts (MA) Dam } \\
\text { Safety }\end{array}$ & Personal communication*, NBEP \\
\hline $\begin{array}{l}\text { Brook Trout Habitat } \\
\text { (polygon) }\end{array}$ & $\begin{array}{l}\text { Eastern Brook Trout Joint } \\
\text { Venture (EBTJV) }\end{array}$ & $\begin{array}{l}\text { http://easternbrooktrout.org/reports/ebtjv-salmonid- } \\
\text { catchment-assessment-and-habitat-patch-layers/view }\end{array}$ \\
\hline $\begin{array}{l}\text { National Rivers and } \\
\text { Streams (polyline) }\end{array}$ & $\begin{array}{l}\text { National Hydrography } \\
\text { Database }\end{array}$ & nhd.usgs.gov \\
\hline $\begin{array}{l}\text { Coldwater Streams } \\
\text { (polyline) }\end{array}$ & $\begin{array}{l}\text { Massachusetts Division of } \\
\text { Fisheries and Wildlife } \\
\text { (MADFW) Coldwater Fisheries } \\
\text { Resources (CFRs) }\end{array}$ & $\begin{array}{l}\text { http://www.mass.gov/anf/research-and-tech/it-serv-and- } \\
\text { support/application-serv/office-of-geographic- } \\
\text { information-massgis/datalayers/dfwcfr.html }\end{array}$ \\
\hline $\begin{array}{l}\text { National Wetlands } \\
\text { Inventory (polygon) }\end{array}$ & $\begin{array}{l}\text { U.S. Fish and Wildlife Service } \\
\text { (USFWS) }\end{array}$ & https://www.fws.gov/wetlands/data/data-download.html \\
\hline $\begin{array}{l}\text { RI Lakes, Ponds, and } \\
\text { Reservoirs (polygon) }\end{array}$ & $\begin{array}{l}2012 \text { Integrated Water Quality } \\
\text { Monitoring and Assessment } \\
\text { (IWQMA) }\end{array}$ & www.rigis.org/data \\
\hline $\begin{array}{l}\text { MA Major Ponds and } \\
\text { Major Streams } \\
\text { (Polygon) }\end{array}$ & U.S. Geological Survey (USGS) & $\begin{array}{l}\text { www.mass.gov/anf/research-and-tech/it-serv-and- } \\
\text { support/application-serv/office-of-geographic- } \\
\text { information-massgis }\end{array}$ \\
\hline MA Wetlands (polygon) & $\begin{array}{l}\text { Department of Environmental } \\
\text { Protection (DEP) Wetlands } \\
\text { Conservancy Program (WCP) }\end{array}$ & $\begin{array}{l}\text { www.mass.gov/anf/research-and-tech/it-serv-and- } \\
\text { support/application-serv/office-of-geographic- } \\
\text { information-massgis }\end{array}$ \\
\hline $\begin{array}{l}\text { Degraded Coastal } \\
\text { Wetlands of } \\
\text { Narragansett Bay } \\
\text { (polygon) }\end{array}$ & $\begin{array}{l}\text { Rhode Island Coastal } \\
\text { Resources Management } \\
\text { Council }\end{array}$ & http://www.rigis.org/data/nbdegrade \\
\hline $\begin{array}{l}\text { HUC12 watershed } \\
\text { areas (polygon) }\end{array}$ & $\begin{array}{l}\text { Natural Resources } \\
\text { Conservation Service }\end{array}$ & https://datagateway.nrcs.usda.gov/ \\
\hline $\begin{array}{l}\text { Stream Order at dams } \\
\text { (point) }\end{array}$ & University of Rhode Island & $\begin{array}{l}\text { Gold et al. } 2016 \text { and } \\
\text { Personal communication*, NBEP }\end{array}$ \\
\hline World Ocean Basemap & ESRI ArcGIS Online & ArcMap 10.3 \\
\hline
\end{tabular}

*Eivy, Monroy, Narragansett Bay Estuary Program, pers. comm; November/2015. 
From this initial compilation, projects that had been planned or designed but not yet completed as of 31 December 2016 were removed from the project list and the remaining projects sorted by restoration type. The list of projects were separated into the following: (1) fish passage obstructions, (2) marsh projects, (3) eelgrass projects, (4) shellfish projects, and (5) other restoration projects. In addition to name, latitude, longitude, and source, additional information provided for most projects included the stated project purpose, habitat restoration type, restored area (acres), resource of concern (i.e., target species), year of project, and nearest town. Further information about observed fish utilization or passage condition was provided for some projects. Although several species of fish were mentioned in the collected data for fish passage, the vast majority were river herring (alewife and blue back herring), American shad, brook trout, and eel. Atlantic salmon was also frequently referenced as an additional target species but the SME recommended focusing analysis on only the first five because salmon restoration has not been successful in southern New England.

The projects were mapped in a GIS, along with the National Hydrology Database (NHD) flowlines and NEBP study area. Datasets were gathered and provided by partners at the state level, therefore, projects outside the Narraganset Bay watershed were eliminated from analysis (Figure 1). Project names and location were compared, and potential duplicates were noted and provided to the project SMEs to confirm and eliminate duplicate projects. Projects that were close to, but not on, flowlines were noted and submitted to the SMEs for review. This same group was asked to provide any projects missing from the databases, and to identify project information that was incorrect or missing. Following a general meeting of project leaders and experts, NOAA RC provided several additional shellfish projects as well as "other" restoration projects ${ }^{1}$. New projects were researched and were sought online in sources such as news articles, the sources for this information are cited in the project list (Appendix A). The website http://www.latlong.net/ was used to obtain approximate latitude and longitude values for projects without location data, using print maps and written descriptions to identify the location.

1 James Turek, NOAA Fisheries Restoration Center; pers. comm; May/2016 


\subsection{Fish passage analysis}

The fish passage analysis was conducted using ArcMap 10.3 and all data displayed using the Rhode Island State Plane (NAD 1983 2011) coordinate system. Although the NEBP study area is large, the fish passage projects targeting anadromous fish are concentrated near the Bay in ten subwatersheds: Ten Mile River, Woonasquatucket River, Palmer River, Pawtuxet River, Hunt River, Taunton River, Pettaquamscutt River, Upper Narragansett Bay, Lower West Passage (west of Aquidneck Island), and Sakonnet River (east of Aquidneck Island). HUC12 watersheds were nested by HUC10 name to obtain the bounding areas, all other data was clipped to only these regions. Flowlines from the Bay to the first dam project on each major river were selected and exported as a new layer, identified as "previously open river" (Figure 2). Flowlines extending upstream from the first fish passage project through adjacent projects and to the next remaining obstruction were selected and exported as a new layer identified as "new open river." This new open length is assigned to anadromous fish (river herring and shad). Eel benefit from complete dam removal and eel ramps but not fish ladders as the flow rate and depth is too high for juvenile eel to navigate. Flowlines from the first dam removal or eel ramp project to the next obstruction without eel passage were selected and exported as a new layer for "new eel access." Brook trout can be anadromous, but some river populations exist in isolated upstream regions. For this analysis, the brook trout habitat patch data was intersected with the "new open river" area and the resulting river segments identified as "brook trout habitat- estuary connectivity restored." Importantly, species passage was not confirmed at these sites, rather, completed projects were assumed to be successful for the analysis.

Figure 2. Diagram describing how the river lengths associated with restoration for various species were identified.

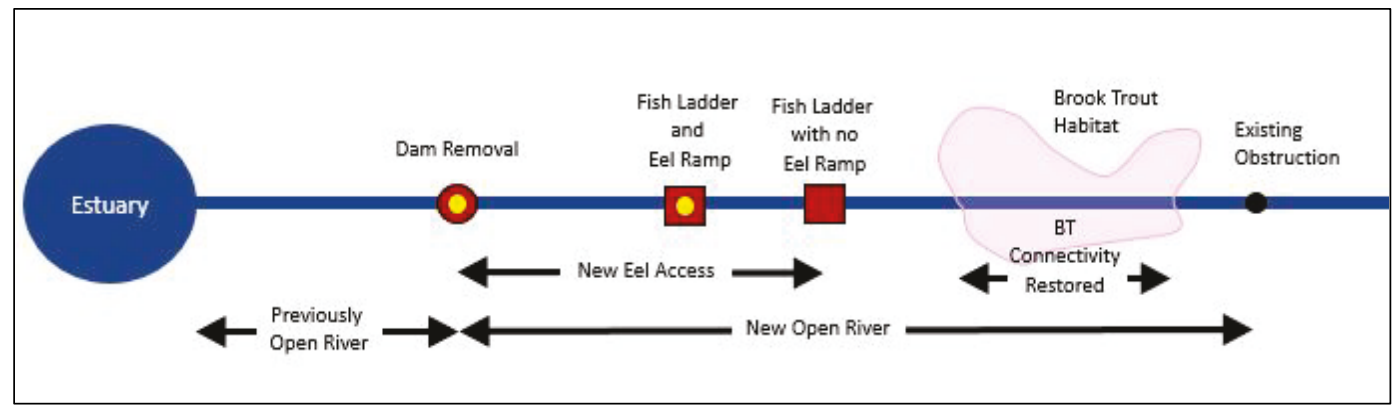


Further calculations of cumulative benefits require not just the length of river, but the area of river opened to the target species. For this analysis, the lakes, ponds, and reservoirs polygons were added to the map and features greater than 0.2 hectares ( 0.5 acres) that intersected a segment of "new open river" were kept. The length of river polyline within these lake features was removed to avoid double counting any area. Using the NHD flowline dataset and the Strahler method (Strahler 1957), stream order was assigned to each remaining "new open river" segment. Stream orders in the study area ranged from one to five. Gold et al. (2016) report stream order at 53 sites relevant to this study. This information was used to validate the stream order assessment. Stream order was used to estimate river width. The length tool in Google Earth Pro was used to measure stream width on several sections of the Ten Mile, Hunt, and Palmer rivers, however, the relative flat topography of the coastal region and resulting marshy land cover prevents effective measurement with aerial photography on smaller streams. A local SME (James Turek of NOAA RC) provided a range of estimates for stream orders 1-4 in the Narragansett Bay region, and field measurements reported by Hughes et al. (2011) were used to extrapolate a steam order/bankfull width curve for the Northern Appalachian Plateau, including New England. These three sources were aggregated to generate the average steam width estimates in Table 2.

Table 2. River width estimates by stream order.

\begin{tabular}{|c|c|c|}
\hline Stream Order & Width $(\mathrm{ft})$ & Width $(\mathrm{m})$ \\
\hline 1 & 7.5 & 2.3 \\
\hline 2 & 15 & 4.6 \\
\hline 3 & 30 & 9.1 \\
\hline 4 & 60 & 18.3 \\
\hline 5 & 120 & 36.6 \\
\hline
\end{tabular}

The stream order data were joined with the edited "new open river" and used to calculate new open river area. The selected lake areas were added to the calculated river area to determine a final area of newly accessible freshwater habitat for each species.

A final analysis was performed to estimate the length of river that would be opened with the removal of an additional single obstruction. When alteration of a single site resulted in utilization of substantial lengths of river (13 to $85 \mathrm{~km}$ ), those potential future projects were considered in the 
category of "low hanging fruit." Terminal dams were selected for this analysis visually. Using the obstruction data layer, the area upriver of the terminal dams was checked to determine if there were low hanging fruit, or considerable river lengths that could be accessed by fish if the terminal dam was removed. New data layers were created for the flowlines of these low hanging fruit projects.

\subsection{Other project analysis}

Shellfish, eelgrass, marsh, other restoration project information were also imported into ArcMap in separate GIS layers. The reported size of each project (when available) was included although mapped boundaries were not available. All of the reported projects were implemented between 1999 and 2016. Shellfish projects were displayed by the target shellfish species. For projects without an identified target shellfish species, the site was labeled generically as shellfish. 


\section{Results}

Restoration project information collected from the various sources was categorized into groups by restoration type. The initial compilation of projects was reviewed by local, regional, and federal partners that were contacted to actively participate in the project. In total, 177 projects were identified between 1999 and 2016: fish passage restoration (46), marsh restoration (35), eel grass restoration (22), shellfish restoration (43), and other projects (31). The overall approach established a comprehensive database on all restoration projects performed in the Narragansett Bay watershed since 1999 (Figure 1).

\subsection{Fish passage}

Analysis of river flowlines from Narragansett Bay to the first unpassable obstruction allows the calculation of the miles of river that have been opened to fish passage (Table 1). The upper reaches of each stream was considered to be accessible, regardless of stream order, flow, or other habitat factors, for its length up to the first identified unpassable obstruction. Identification of the type of passage along these routes allows determination of whether specific species can pass a specific obstruction. The presence of eel and/or anadromous fish ladders were used to characterize which lengths were passable, or not passable, for a taxa, whereas, removal of an obstruction indicated that that length of river was fully opened. The analysis indicated that river herring and shad have benefited from the most opened river length over the last two decades, with more than $850 \mathrm{~km}$ of river access added. Additionally, Eel ladders have resulted in the opening of more than $430 \mathrm{~km}$ of accessible habitat for American eel. Based on the estimated average width of these rivers (Table 2), an area opened for the utilization of each species was calculated. This includes the lands and ponds that are linked to, or traversed by, the newly accessible river distances added to the estimated hectares of habitat available. Following these calculations, river herring and shad have gained the most habitat area from the restoration work included, estimated at 4,930 hectares (ha). 
Table 3. Length and area of river opened by taxa.

\begin{tabular}{|l|c|c|c|c|c|}
\hline & $(\mathbf{a})$ & (b) & (c) & (d) & (c)+(d) \\
\cline { 2 - 6 } & $\begin{array}{c}\text { Fully Opened } \\
(\mathbf{k m})\end{array}$ & $\begin{array}{c}\text { New River } \\
\text { Access } \\
(\mathbf{k m})\end{array}$ & $\begin{array}{c}\text { New River Area } \\
\text { Taxa }\end{array}$ & $\begin{array}{c}\text { New Lake Area } \\
\text { (ha) }\end{array}$ & $\begin{array}{c}\text { Freshwater Area } \\
\text { Opened } \\
\text { (ha) }\end{array}$ \\
\hline Eel & 322 & 407 & 390 & 260 & 650 \\
\hline $\begin{array}{l}\text { Alewife Herring, } \\
\text { Blueback Herring, } \\
\text { and Shad }\end{array}$ & 322 & 826 & 580 & 4300 & 4880 \\
\hline Brook Trout* & $\mathrm{n} / \mathrm{a}$ & 154 & $\mathrm{n} / \mathrm{a}$ & $\mathrm{n} / \mathrm{a}$ & $\mathrm{n} / \mathrm{a}$ \\
\hline
\end{tabular}

*Brook Trout habitat exists in pockets as shown by the EBTJV study. The distance listed for Brook Trout in the table above is the river distance in new river access that intersects with Brook Trout habitat.

The Taunton River, Palmer River, Pawtuxet River, Upper Narragansett Bay, and Lower West Passage watersheds all had a dam removal project on the first dam moving upstream from the estuary. These removals collectively opened an additional $350 \mathrm{~km}$ of river with unobstructed connectivity to the bay. Fish passages and upstream dam removal provided an additional $85 \mathrm{~km}$ of river access for eel, and an additional $504 \mathrm{~km}$ of river access for river herring and shad. The projects reconnected $154 \mathrm{~km}$ of established upstream brook trout habitat to the bay.

Maps show the locations and extent of the river miles opened in the different watersheds (Upper Narragansett Bay, Pawtuxet River, Woonasquatucket River, Ten Mile River, Palmer River, Taunton River, Sakonnet River, Lower West Passage, Pettaquamscutt River, and Hunt River) (Figures 3-12). Technical fishways do not pass all species of fish and may not pass target species as effectively as dam removal (Noonan et al. 2011). Performance monitoring is not available for all projects to provide a consistent analysis. This effort assumes all installed fish passages work as designed and that all river miles opened represent suitable habitat for the target species.

Each watershed shows a collection of projects that increase the access to spawning habitat for anadromous fish species. In the upper Narragansett Bay (Figure 3) watershed there are several small streams that feed directly into the bay. Restoration projects were performed on five of these. Prior to any of the identified dam removal projects, $8.7 \mathrm{~km}$ of river was open to the Bay on these five sub-watersheds. One dam removal and eight fish passages of various types were installed, opening an additional $16.5 \mathrm{~km}$ of 
river for river herring, shad, and eel. Alewife and shad can now access 120 ha and eel access $1.1 \mathrm{~km}$ of lake (lentic) habitat. However, it should be noted that the additional habitat ( $120 \mathrm{ha}$ ) is a man-made lake connected to the bay via an artificial canal. There is no brook trout habitat on these streams (according to the GIS layer defining that habitat).

The Pawtuxet River watershed (Figure 4) previously contained no sections of river with open access to the Bay. With the removal of the Pawtuxet Falls Dam in 2011 (USDA-NRCS 2017), $22.5 \mathrm{~km}$ and 10 ha of river were opened to fish passage, and $5.4 \mathrm{~km}$ of upstream brook trout habitat was connected to the Bay. Figure 4 also shows a dam located approximately 2 $\mathrm{km}$ upstream of the mouth. The Silver Hook dam is a small feature on a side tributary of the mainstem. Additionally, there is a small dam identified just south of the junction of the Pawtuxet and Pocasset rivers. While the Pettaconsett Dam exists in the database, aerial photography from Google Earth, and reports from SMEs, indicate that it was either removed at some point, or is no longer an obstruction. For this analysis, it was assumed that the dam was removed by parties unknown to the project team and SMEs.

Before 1999, the Woonasquatucket River (Figure 5) had $3.3 \mathrm{~km}$ of river open to the Bay. Two dams were removed and three fish ladders and two eel ramps were installed during the study period. This resulted in an additional $5.5 \mathrm{~km}$ opened for herring and shad passage, and $3.6 \mathrm{~km}$ for eel. All species now have access to 8 ha of lake waters. There is no brook trout habitat in this opened section of river (according to the GIS layer of identified brook trout habitat). At the time of this report, the eel ramp at the Rising Sun dam was reported to be non-functioning, ${ }^{1}$ so no benefits were realized as a result.

The Ten Mile River (Figure 6) previously supported no direct connectivity with the Bay, although anadromous fish have been hand-lifted over the Omega Pond Dam by volunteers in the past. ${ }^{2}$ Three fish ladders were installed, and two eel ramps are planned for construction in the near future. Now, $9.4 \mathrm{~km}$ and 47 ha of river is accessible to river herring, shad, and eel in this watershed. There is no mapped brook trout habitat in this watershed.

${ }_{1}^{1}$ Phillip Edwards, Rhode Island Department of Environmental Management; pers. comm; May/2016

2 Phillip Edwards, Rhode Island Department of Environmental Management; pers. comm; May/2016 
The Palmer River (Figure 7) previously consisted of $59.5 \mathrm{~km}$ of open river on the mainstem and tributaries. With the removal of an unnamed dam on the Rocky Run branch, an additional $28.1 \mathrm{~km}$ were opened to all fish species studied, although there is no brook trout habitat in the opened region.

The Taunton River and watershed (Figure 8) is located in Massachusetts but drains to Mount Hope Bay. Previously, $112.1 \mathrm{~km}$ of river and tributaries were directly connected to the Bay. Restoration work in the watershed comprised eight fish ladders, two dam removals, and a culvert replacement within the study area. These efforts have opened $576 \mathrm{~km}$ of river and 3,830 ha to herring and shad, including access to the large Assawompset Reservoir. Although no eel ramps were constructed, the single culvert on the mainstem of the river opens $290.7 \mathrm{~km}$ of river and 12 ha habitat area to eel.

The Sakonnet River Watershed (Figure 9) covers the southeast portion of Narragansett Bay. Mary's Creek from the Bay to before Nonquit Pond previously provided $5.85 \mathrm{~km}$ of river access. After the completion of one fish passage, there are now 80 ha in the pond and $27.9 \mathrm{~km}$ of riverine environment open upstream on Bordon Brook for herring and shad. No eel passage or brook trout habitat is present in this area.

The Lower West Passage (Figure 10) covers the southwest portion of Narraganset Bay. During the study period, one dam removal and four fish ladders were constructed on the Annaquatucket River, and one dam removal and one breachable dam were completed on other streams in the watershed. The result is an additional $15.4 \mathrm{~km}$ of river access for herring and shad, and $8 \mathrm{~km}$ for eel. The habitat improvements also include access to 110 ha of lakes for herring and shad and 36 ha for eel. Upstream river brook trout habitat $(6.6 \mathrm{~km})$ was also reconnected to the Bay.

The Pettaquamscutt River (Figure 11) is more commonly referred to as the Narrow River. One fishway with eel ramp was constructed at the headwater, allowing passage into 22 ha of Carr Pond and $10.4 \mathrm{~km}$ upstream into the Mattatuxet River for herring, shad, and eel. These restorations also resulted in $2.4 \mathrm{~km}$ of upstream brook trout habitat being connected via the Narrow River to the Bay.

The Hunt River (Figure 12), was dammed at the river mouth before the study period. The restoration work included three dam removals, one 
partial breach, two fish passages, and one eel passage. These restoration projects resulted in $39.2 \mathrm{~km}$ of river opened for herring and shad, and 2.85 $\mathrm{km}$ for eel. Alewife and shad gained access to 7 ha of lake habitat, and 31.4 $\mathrm{km}$ of brook trout habitat is now reconnected to the Bay. The Audubon Property Dam is currently identified as the terminal dam on the mainstem of the Hunt River. A dam named Hunt/Rt403 with a Denil passage has very similar reported latitude and longitude, but aerial photography indicates that the Audubon Property Dam is still in place with no fish passage. It is assumed that the Hunt/Rt403 Denil is mislocated in the database, therefore, it was not included in the present study. 
Figure 3. Dam passability, river access, and lake access opened in the Upper Narragansett watershed through the collective implementation of Narragansett Bay restoration projects. The displayed watersheds are the HUC-12 that drain into the Upper Bay.

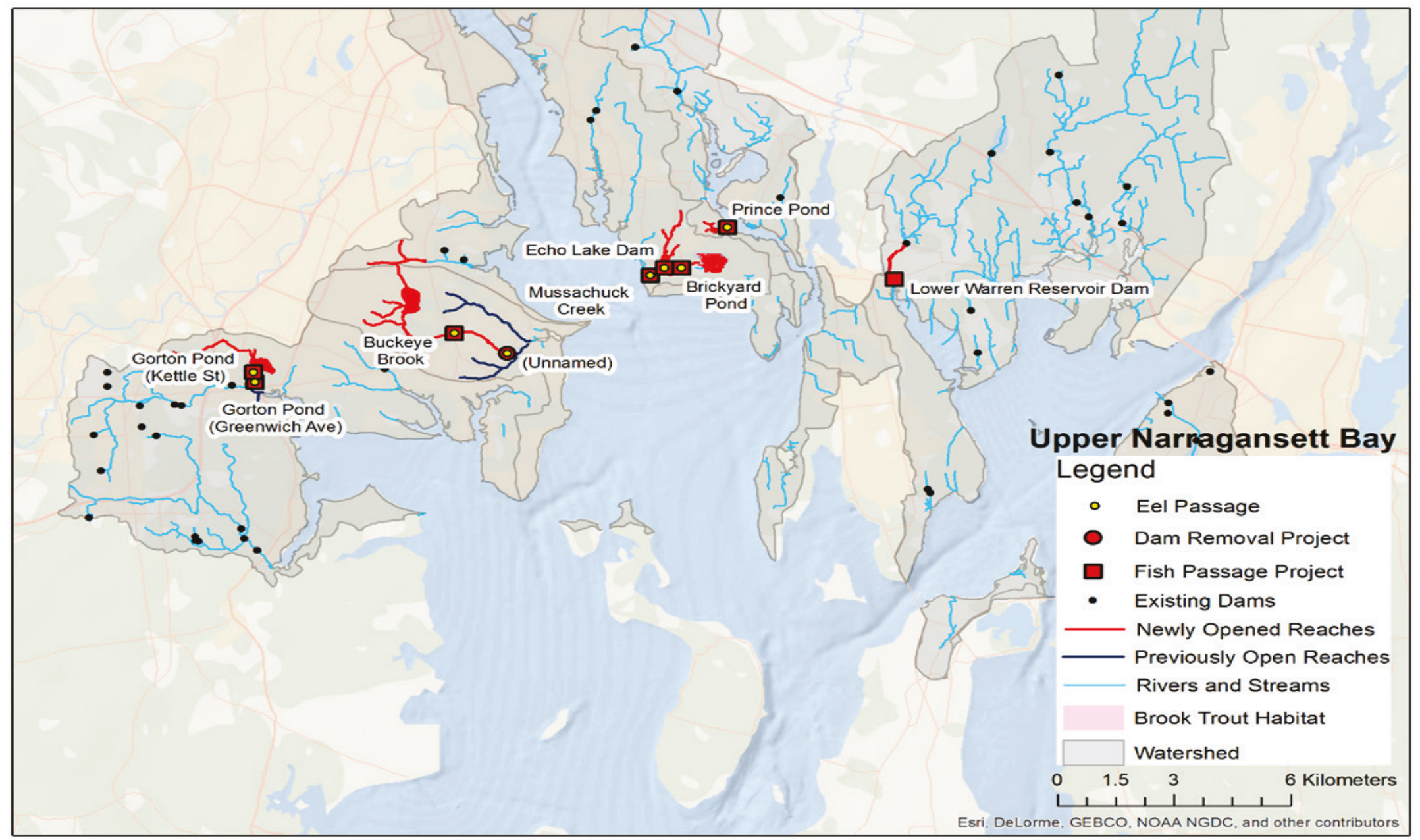


Figure 4. Dam passability, river access, and lake access opened in the Upper Narragansett watershed through the collective implementation of Narragansett Bay restoration projects. The displayed watersheds are the HUC-12 that drain into the Upper Bay.

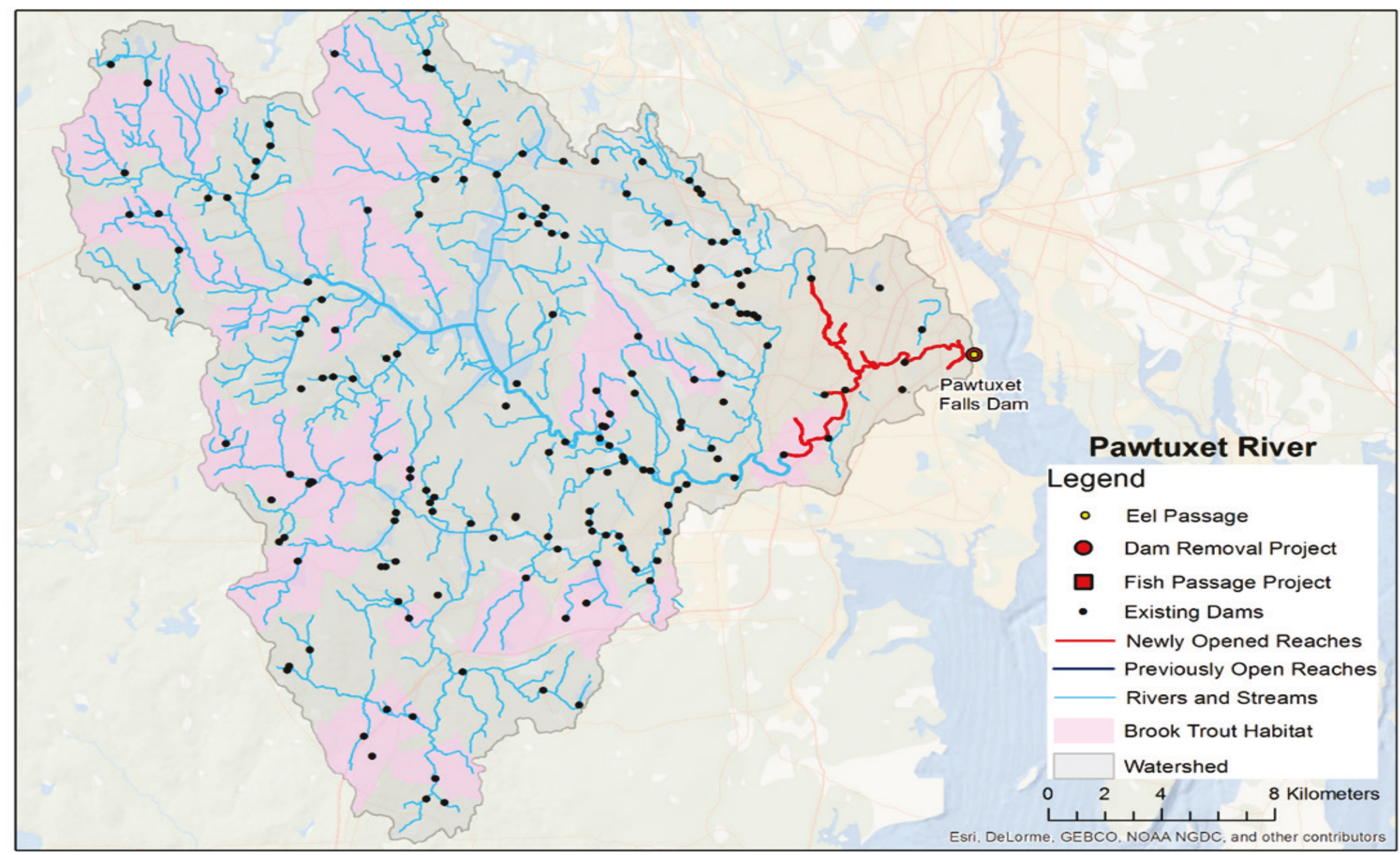


Figure 5. Dam passability, river access, and lake access opened in the Pawtuxet watershed through the collective implementation of Narragansett Bay restoration projects.

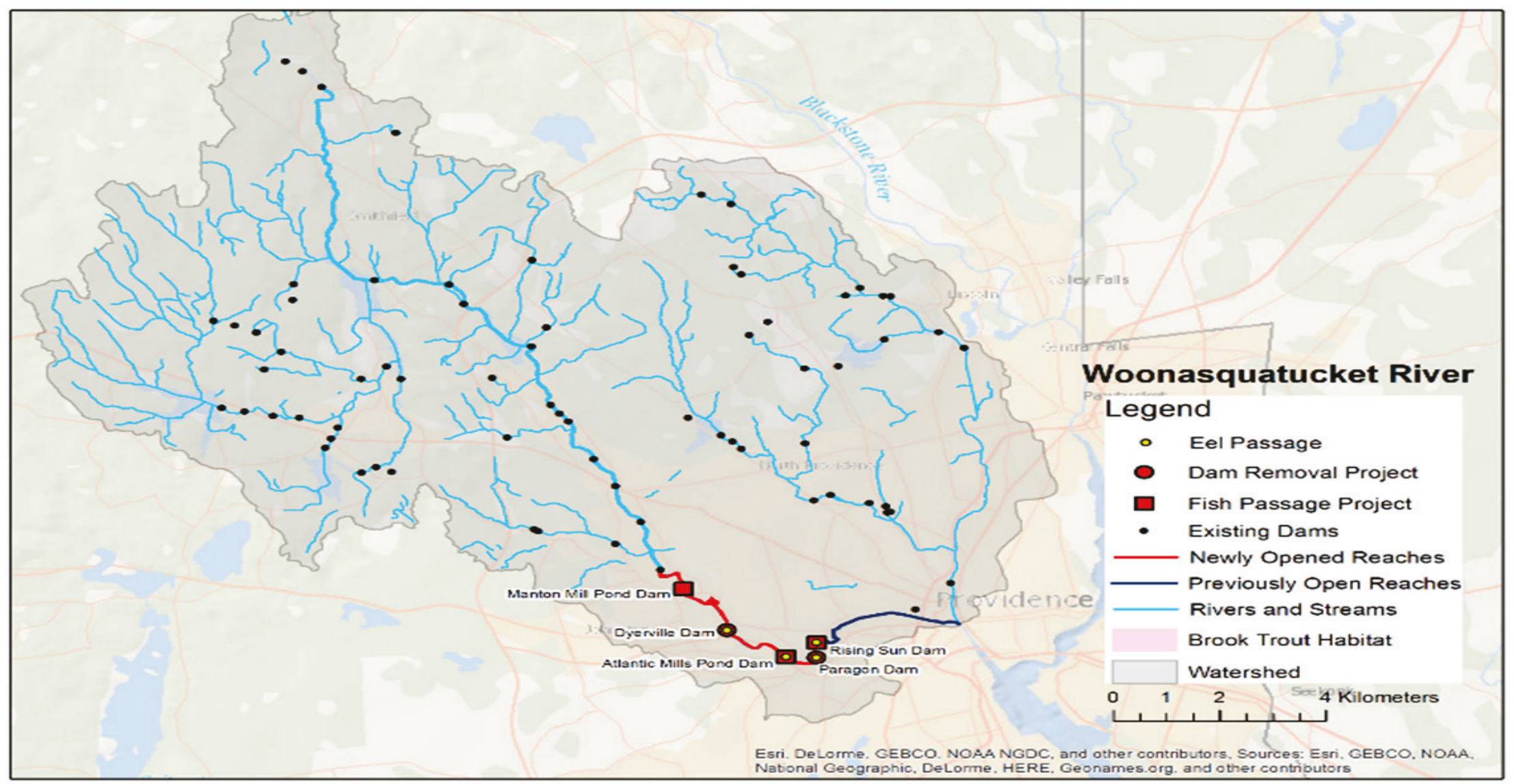


Figure 6. Dam passability, river access, and lake access opened in the Ten Mile watershed through the collective implementation of Narragansett Bay restoration projects.

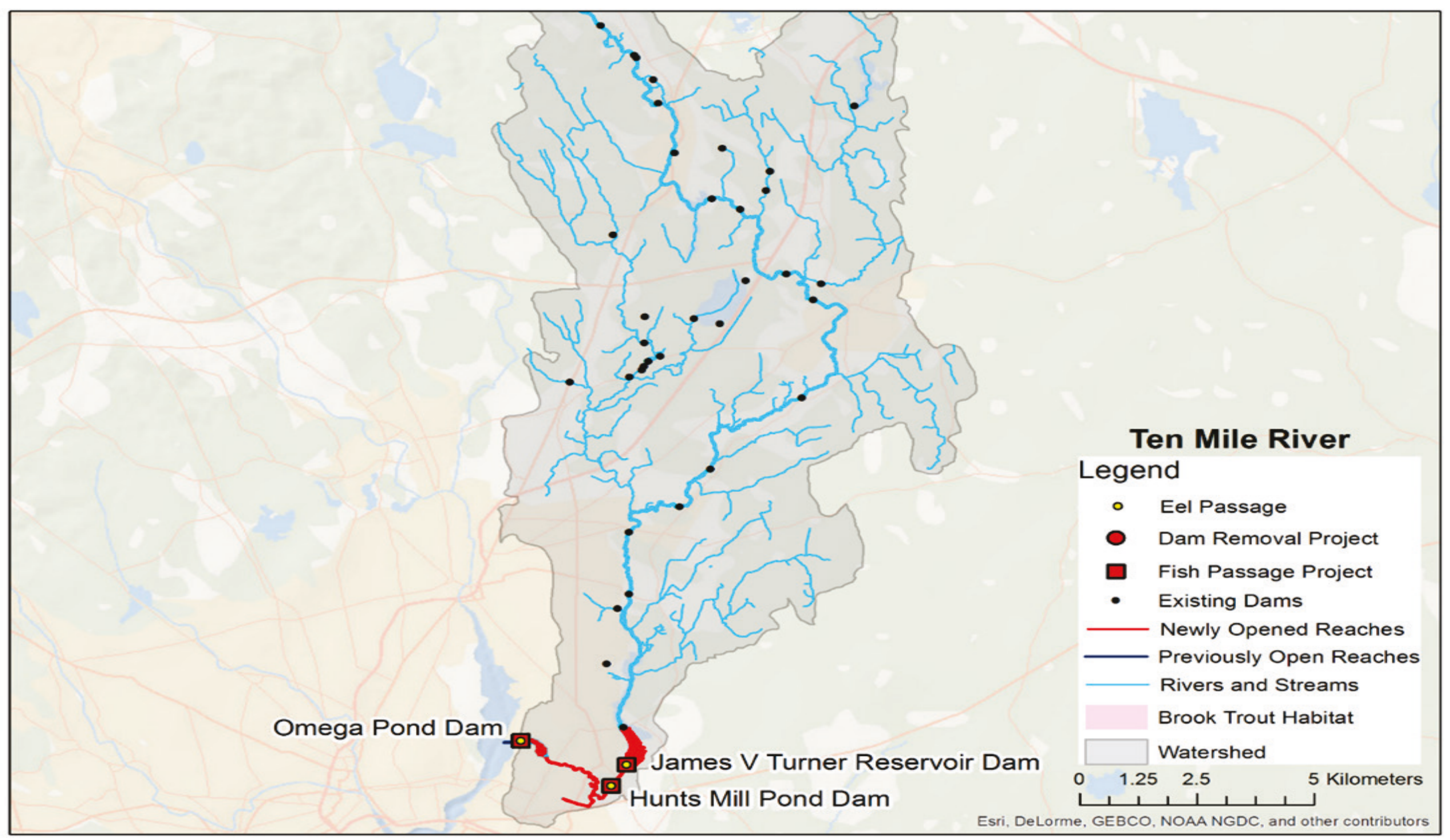


Figure 7. Dam passability, river access, and lake access opened in the Palmer watershed through the collective implementation of Narragansett Bay restoration projects.

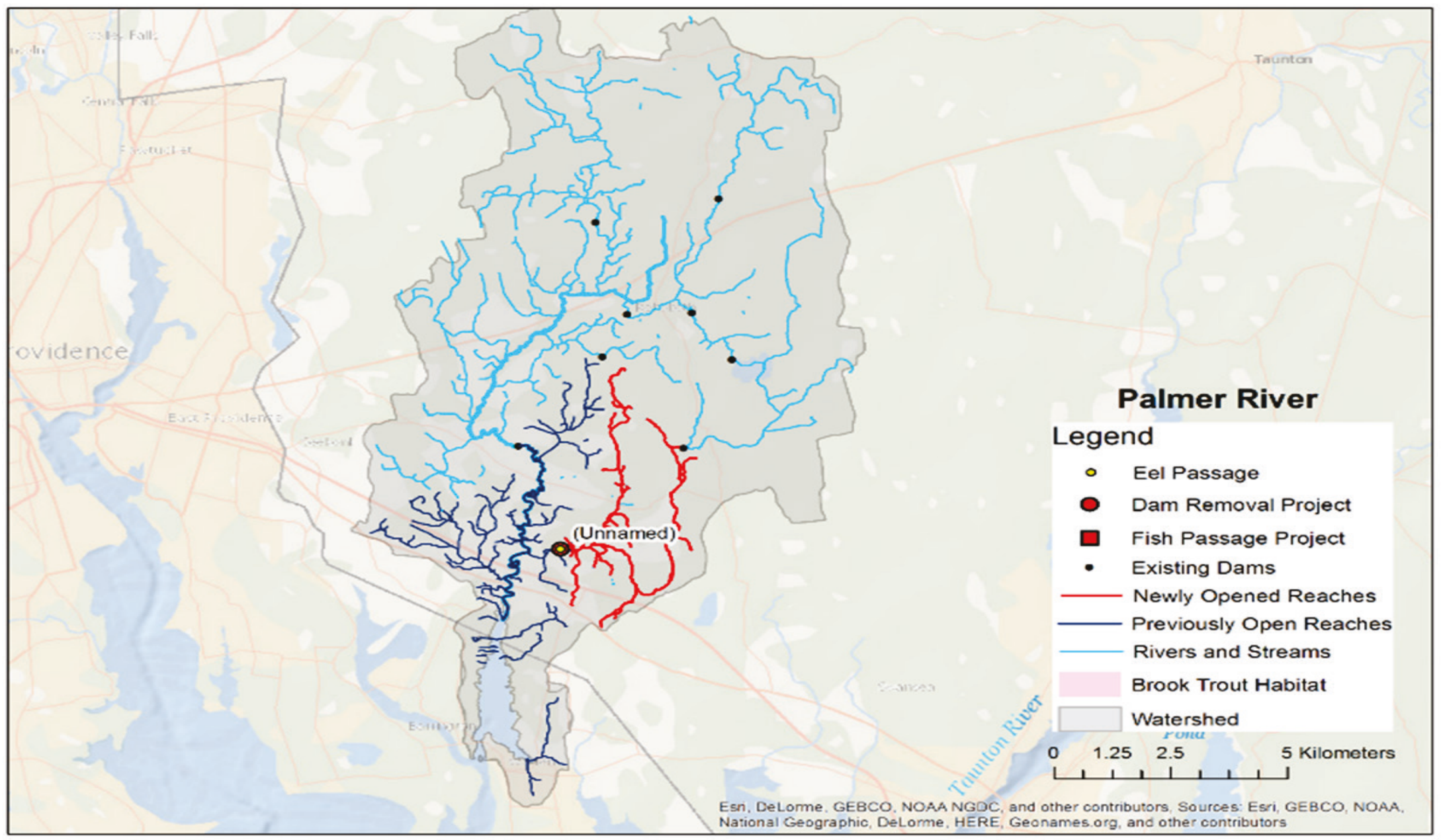


Figure 8. Dam passability, river access, and lake access opened in the Taunton watershed through the collective implementation of Narragansett Bay restoration projects.

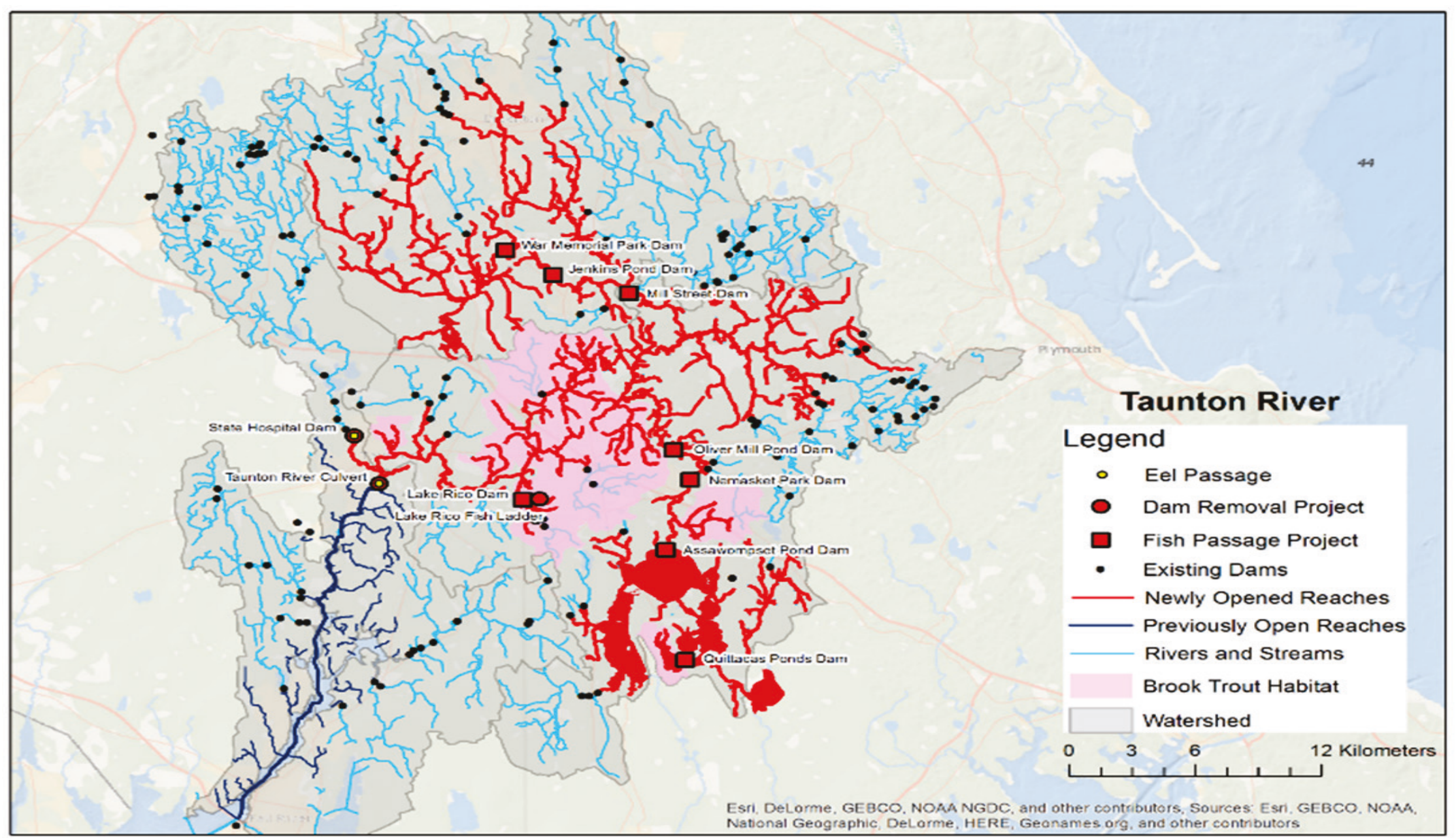


Figure 9. Dam passability, river access, and lake access opened in the Sakonnet watershed through the collective implementation of Narragansett Bay restoration projects.

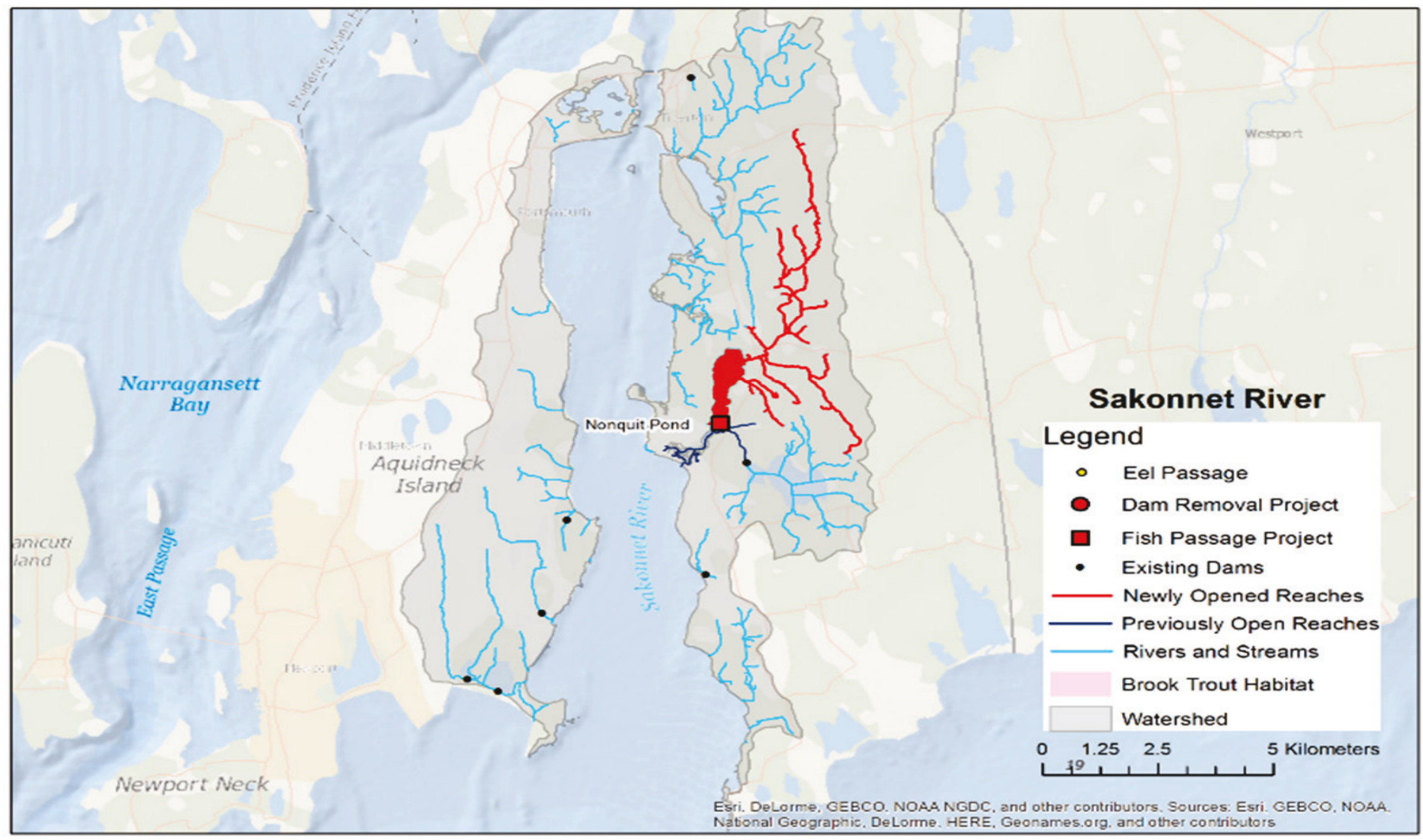


Figure 10. Dam passability, river access, and lake access opened in the Lower West Passage watershed through the collective implementation of Narragansett Bay restoration projects.

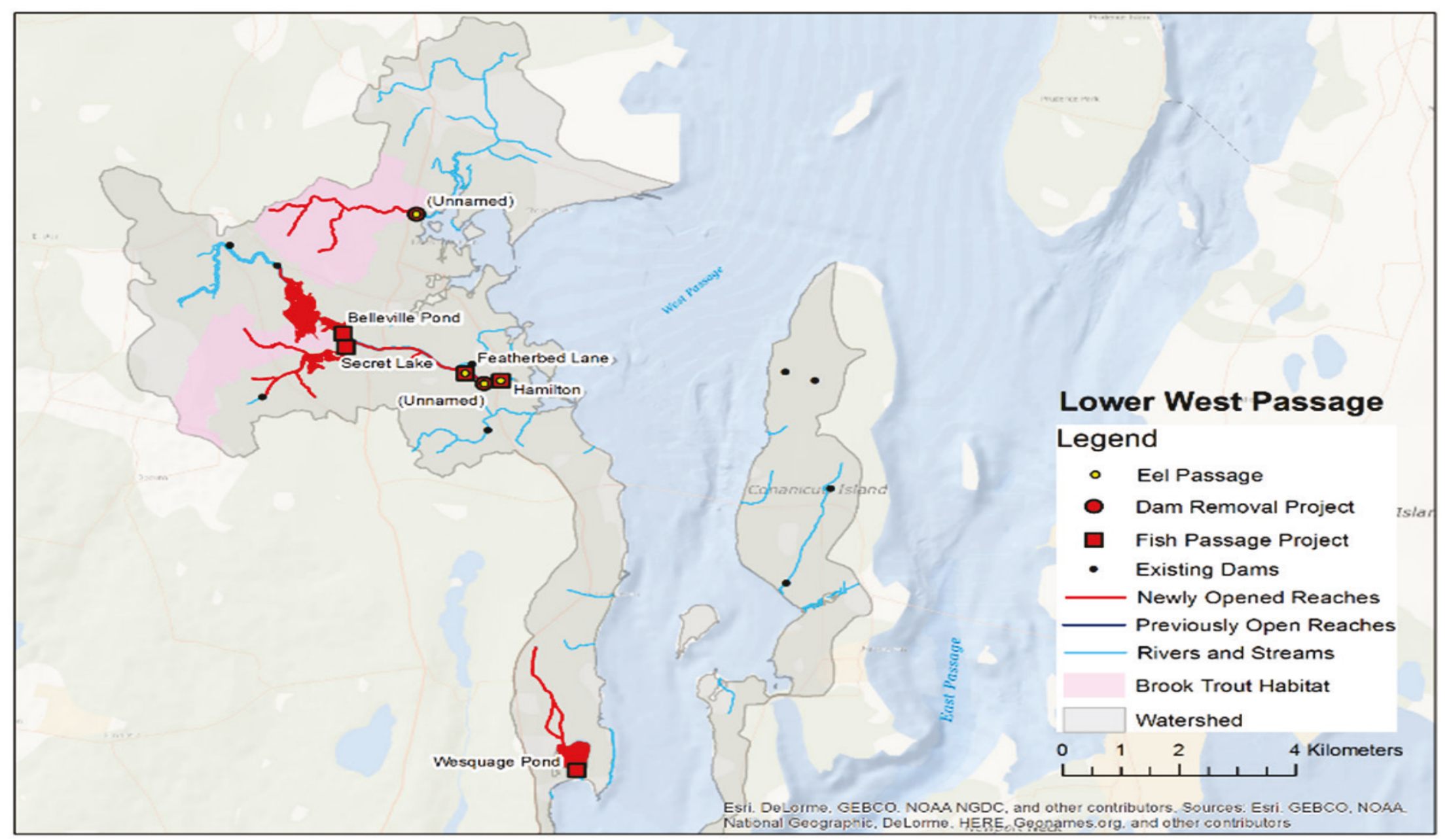


Figure 11. Dam passability, river access, and lake access opened in the Pettaquamscutt watershed through the collective implementation of Narragansett Bay restoration projects.

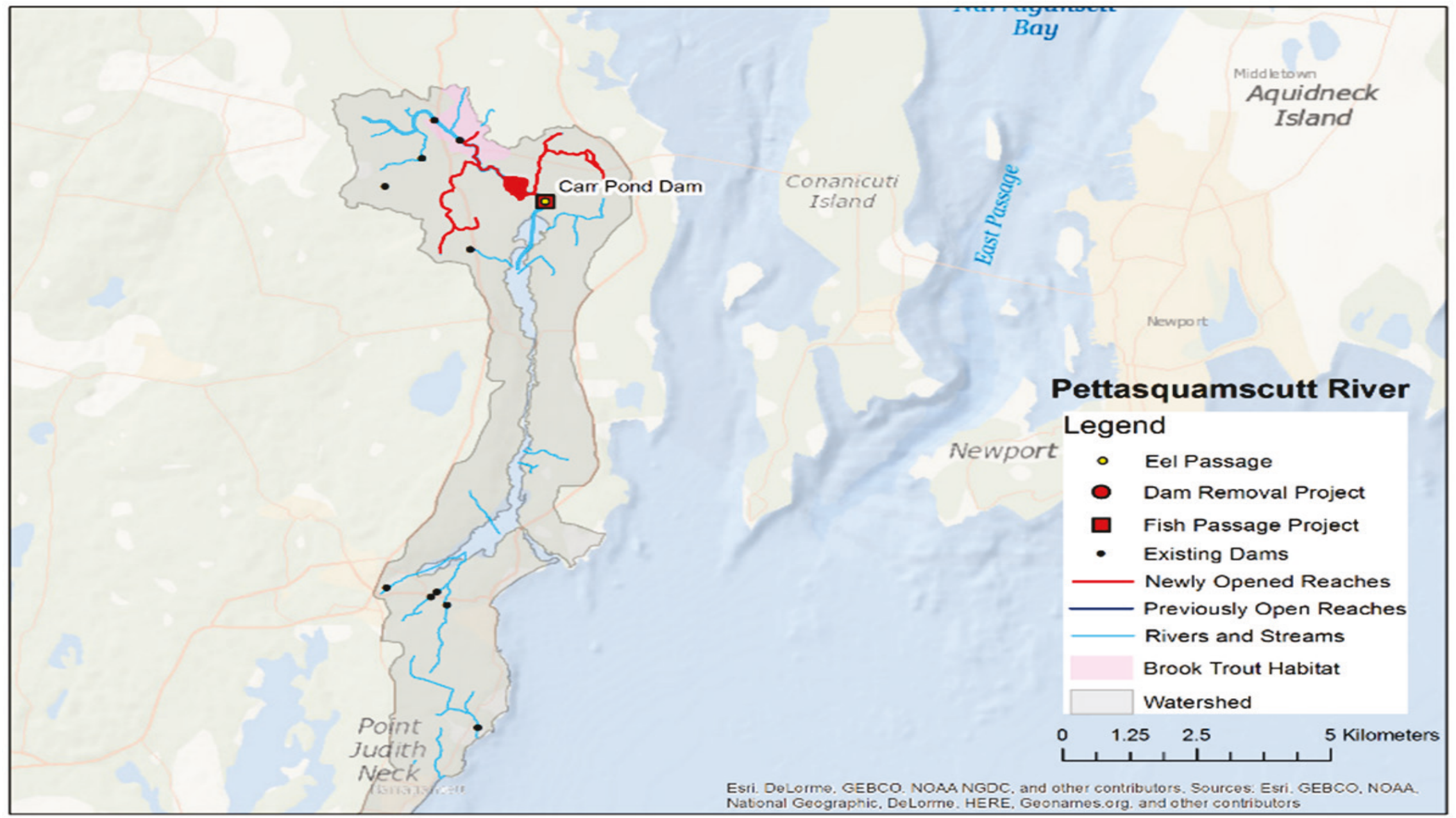


Figure 12. Dam passability, river access, and lake access opened in the Hunt watershed through the collective implementation of Narragansett Bay restoration projects.

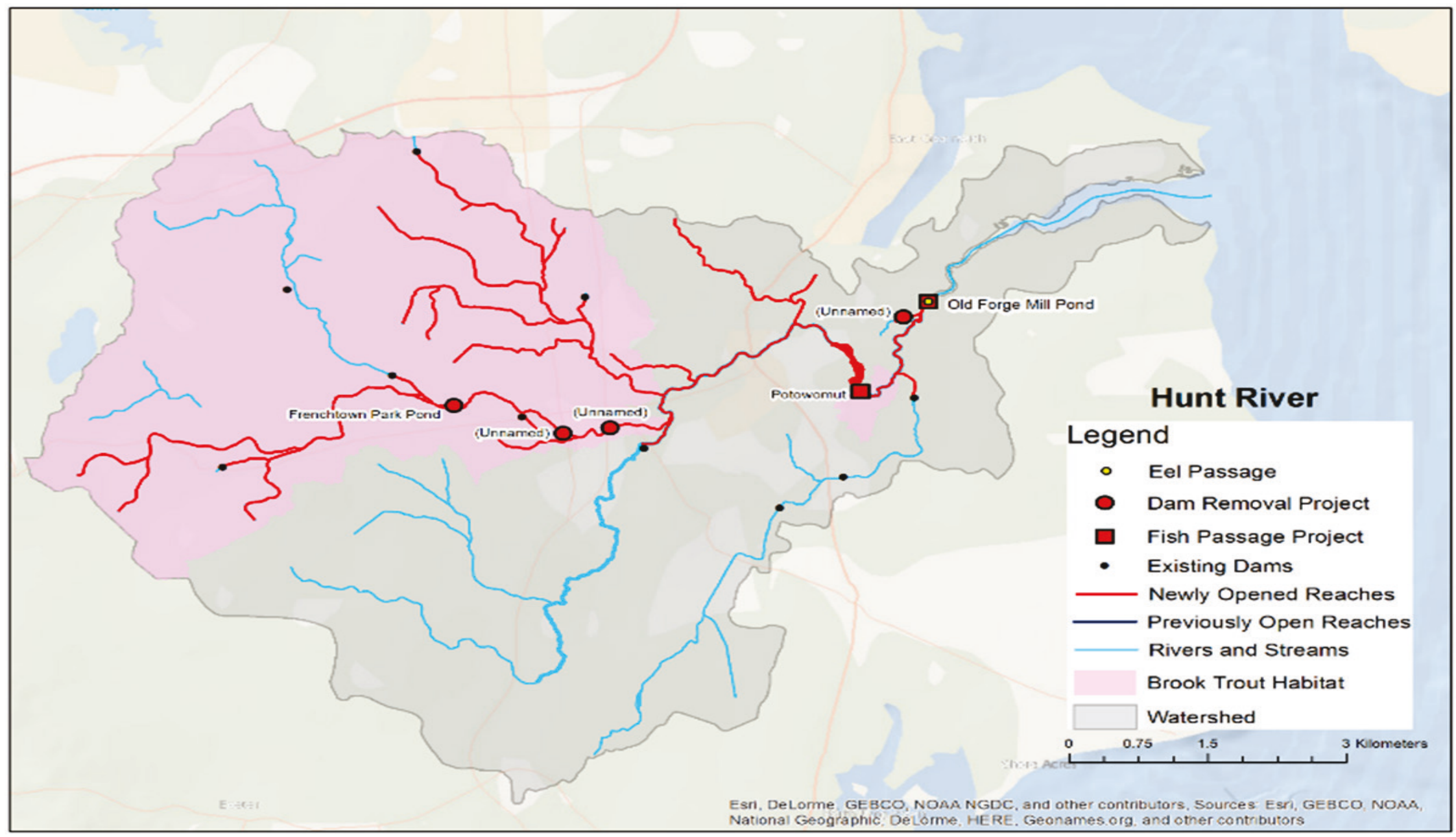




\section{2 "Next step" projects}

Obstructions were identified, based on this analysis of passage that provide the largest area or stretch of habitat for one or more species, if removed. For some of these remaining obstructions, the river miles that would be opened with their removal has been calculated (Table 4). These "next step" projects were also characterized in terms of their benefit to a particular species or group of fish. Removal of the Mill Street Dam and passability of Nonquit Pond was estimated to make available the largest river length of habitat for eel. Removal of obstructions from Forge Pond Dam and Pontiac Mill Dam would allow the most access to much of the currently inaccessible habitat for herring, shad, and other anadromous species.

Table 4. Next step projects for dam removal or fish passage addition.

\begin{tabular}{|c|c|c|c|}
\hline Target & $\begin{array}{c}\text { Dam for removal/fish } \\
\text { passage }\end{array}$ & River & Distance opened $(\mathrm{km})$ \\
\hline Eel & Mill Street Dam & $\begin{array}{l}\text { Taunton Watershed } \\
\text { Matfield River }\end{array}$ & 84.8 \\
\hline Eel & Nonquit Pond & $\begin{array}{l}\text { Sakonnet Watershed } \\
\text { Nonquit Pond, Borden } \\
\text { Brook }\end{array}$ & 30.6 \\
\hline Herring, Eel & Central Pond Dam & Ten Mile River & 30.1 \\
\hline Herring, Eel & Forge Pond Dam, & $\begin{array}{l}\text { Taunton Watershed } \\
\text { Meadow Brook }\end{array}$ & 29.4 \\
\hline Herring, Eel & $\begin{array}{l}\text { Pontiac Mill/Gorton } \\
\text { Pond Greenwich Ave }\end{array}$ & $\begin{array}{l}\text { Pawtuxet Watershed, } \\
\text { Pawtuxet River }\end{array}$ & 21.6 \\
\hline Herring & Watson Reservoir & $\begin{array}{l}\text { Sakonnet Watershed } \\
\text { Almy Brook }\end{array}$ & 18.6 \\
\hline Eel & $\begin{array}{l}\text { Warren Reservoir } \\
\text { Upper Dam }\end{array}$ & Kickamuit River & 18.1 \\
\hline Herring, Eel & Santos Pond Dam & $\begin{array}{l}\text { Palmer Watershed } \\
\text { Rocky Run }\end{array}$ & 18 \\
\hline Herring, Eel & Barstowe's Pond Dam & $\begin{array}{l}\text { Taunton Watershed } \\
\text { Cotley River }\end{array}$ & 16.8 \\
\hline Herring & Cranston Print Works & $\begin{array}{l}\text { Pawtuxet Watershed } \\
\text { Pocasset River }\end{array}$ & 15.6 \\
\hline Herring, Eel & American Screw & $\begin{array}{l}\text { Woonasquatucket } \\
\text { Watershed } \\
\text { Moshassuck River }\end{array}$ & 13.5 \\
\hline Eel & $\begin{array}{l}\text { Rising Sun - exists but } \\
\text { non-functioning }\end{array}$ & Woonasquatucket & 4.23 \\
\hline
\end{tabular}




\subsection{Salt marsh restoration}

Restoration projects were identified as restoring approximately 331 ha of salt marsh. These projects were dispersed throughout the Bay (Figure 13). Size estimations for these projects came from various sources, including some that reported the size of the existing marsh surrounding the restored area. Many of these projects were described as improvements in tidal flushing, either through expanding or replacing culverts or from excavation of inlets. Several projects intended to reduce the area of invasive Phragmites. Specific areas restored were not consistently reported. The amount of land excavated, rewetted, or converted from Phragmites to Spartina species for each project was also difficult to ascertain using available information. Site visits and aerial photography may be used to identify the boundaries and delineated the categories within each salt marsh restoration project. For this analysis, the team hypothesized this distribution of the total collected area into the categories of land excavated, rewetted, or converted from Phragmites to Spartina species in order to demonstrate the calculation of gains in function.

\subsection{Eel grass restoration}

Twenty-two separate and distinct eel grass restoration projects were identified from the submitted information (Figure 14). For nine of those projects, the size of the effort was reported collectively accounting for 4.3 ha. Several projects were described as demonstrations or experimental transplants. Certain project sites were noted as evaluations of the potential of a site for eel grass development. Most of these sites were monitored until eel grass was no longer detected at that area.

\subsection{Shellfish restoration}

Various types of shellfish restoration projects were reported among the 43 that were identified for the Narragansett Bay study area (Figure 15). Note that a majority of the shellfish restoration efforts were occurring in the salt ponds along the southern coast of Rhode Island, outside the Narragansett Bay watershed. Acreage information was reported for only 5 of 43 projects. Those five projects collectively cover 83.3 ha with the majority attributed one project (World Prodigy Grounding - Quahog Spawner Sanctuary). Therefore, the number of potential animals was used, in the place of area, as an indication of project size. Of 38 oyster restoration projects, 35 are collectively responsible for 13,223,211 oysters being seeded or raised and 
placed at a restoration site or shellfish sanctuary. One clam project reported placement of 350,000 pounds of quahog clams in three sanctuaries. All project specific data is archived in the database of Narragansett Bay restoration projects.

Figure 13. Map of Narragansett Bay marsh restoration projects in the study area shown with approximate existing wetland areas from the National Wetlands Inventory V2, and degraded coastal wetlands delineated from 1996 aerial photography.

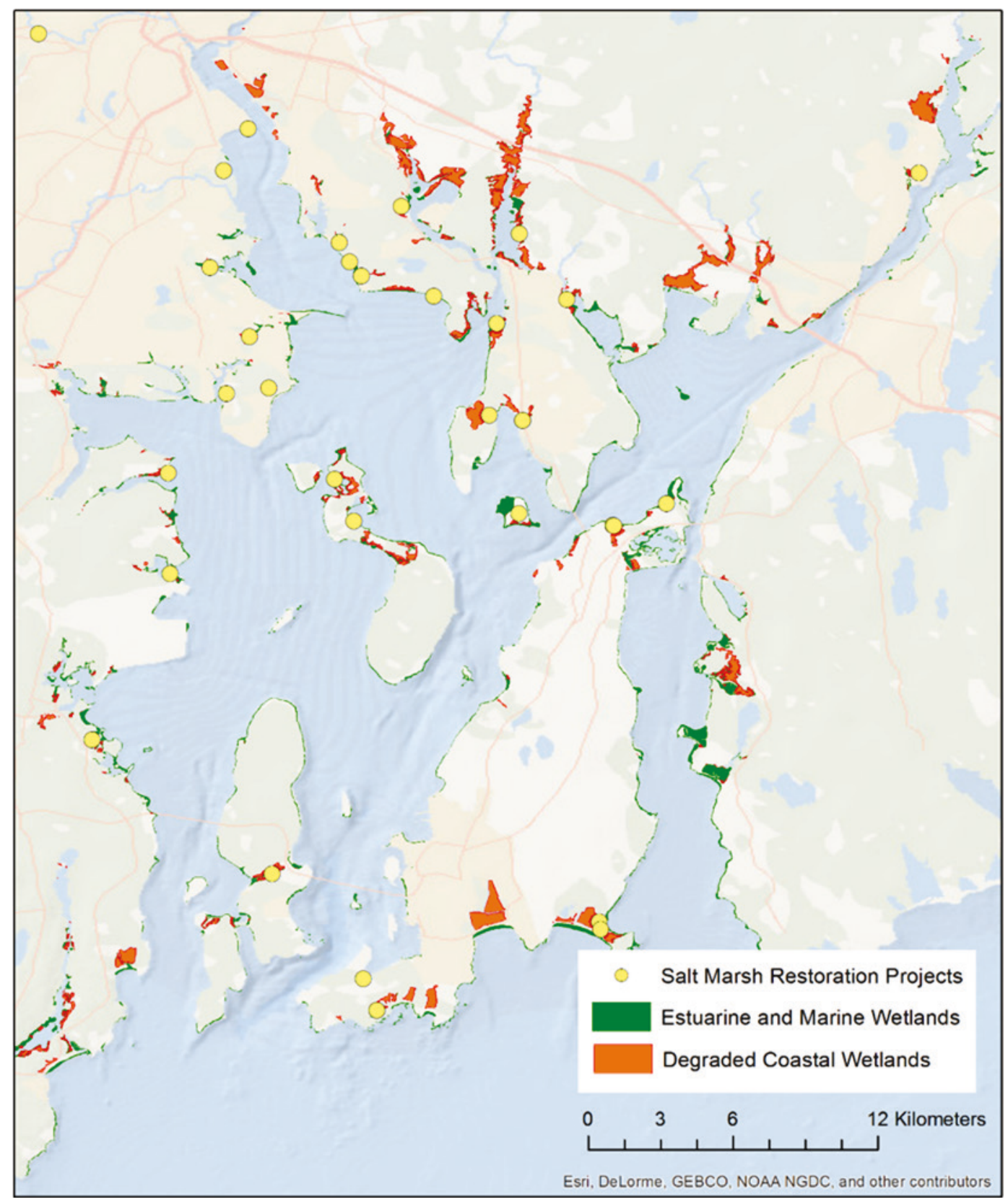


Figure 14. Map of Narragansett Bay eelgrass restoration projects in the study area.

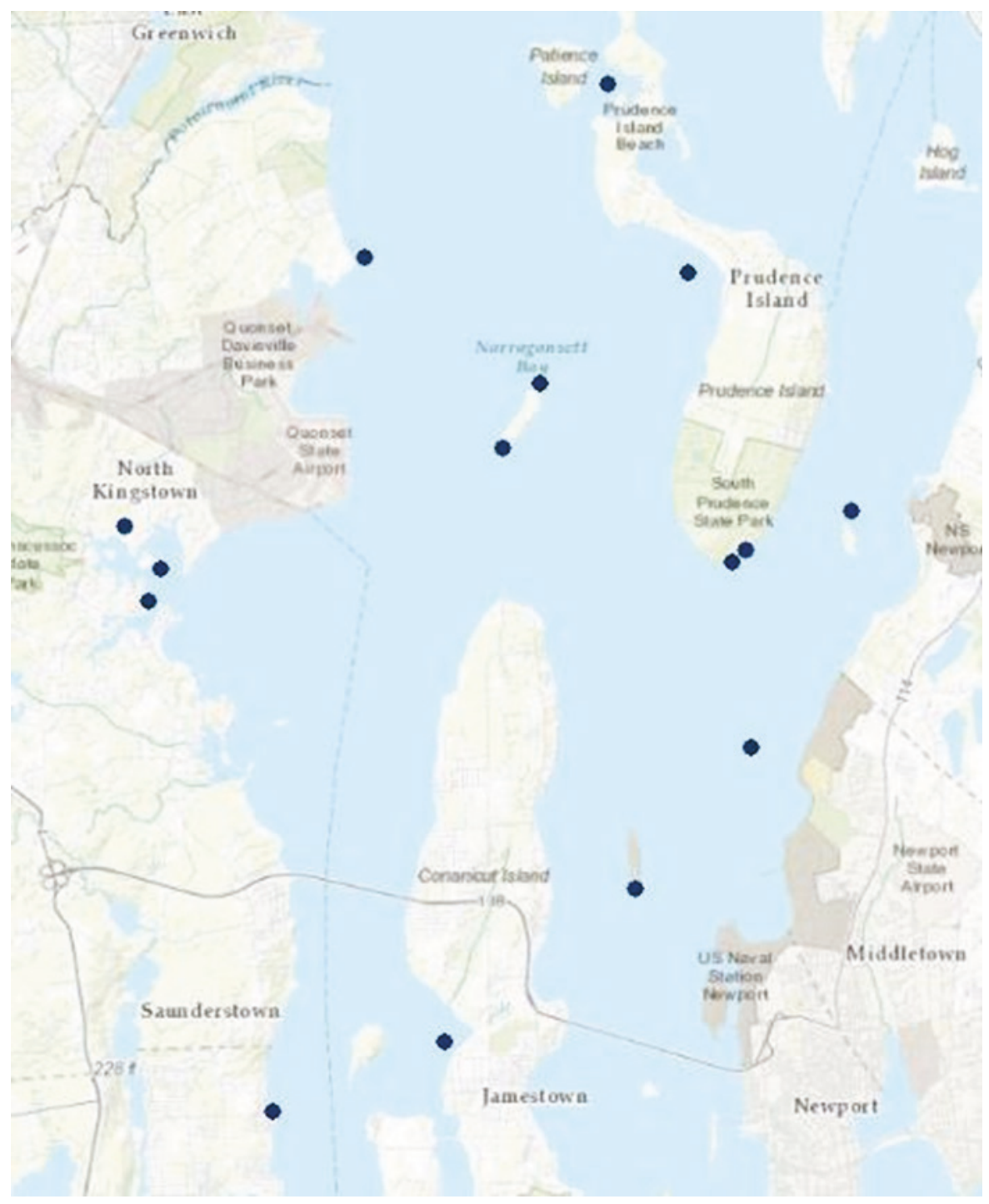


Figure 15. Map of Narragansett Bay shellfish projects. Note that the colors represent different shellfish targets for the projects. Purple circles are for clams. Red circles are for lobster. Orange circles are for oysters. Green circles are for scallops. The remaining project (pink) was reported generally as shellfish enhancement.

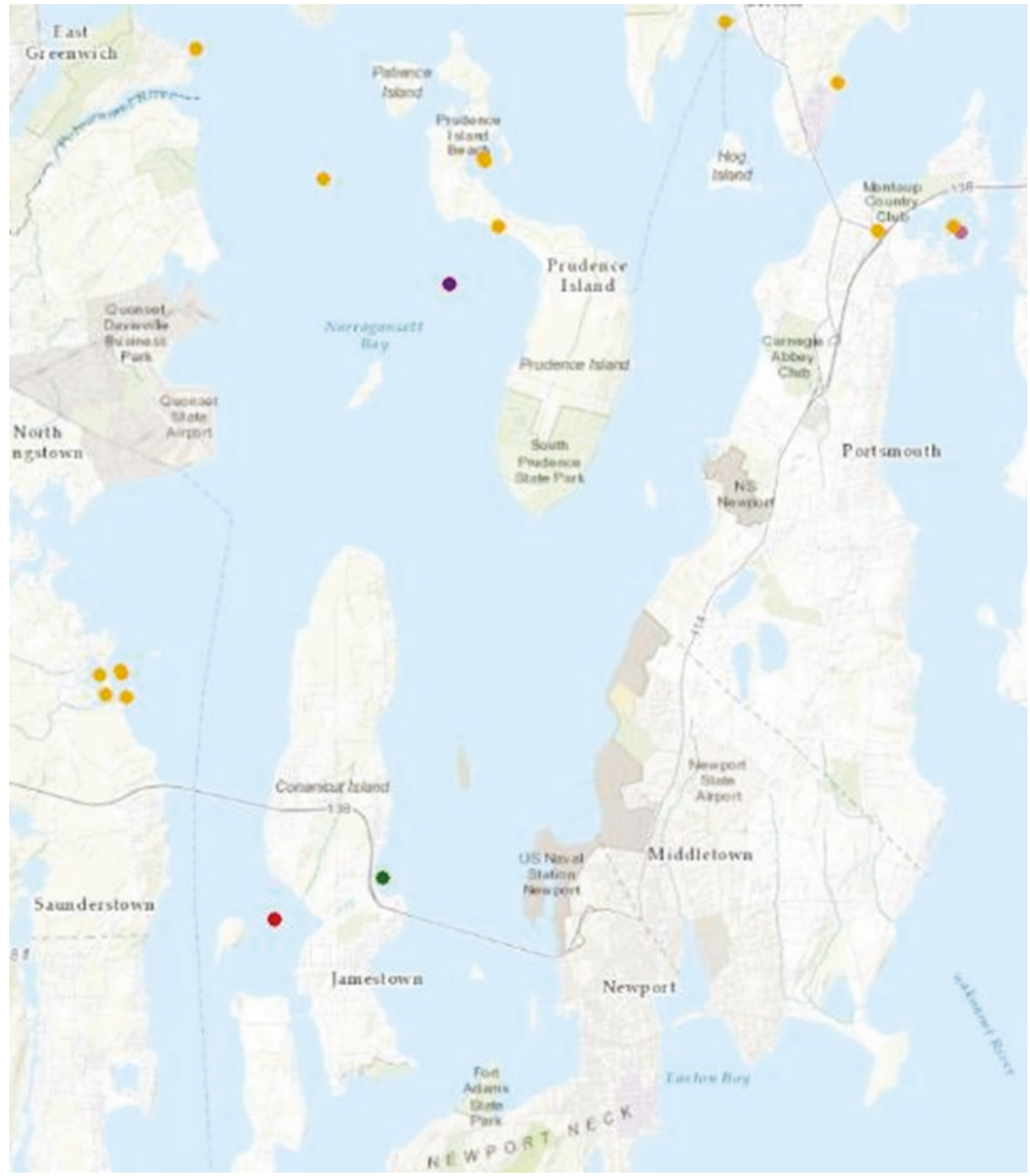

\subsection{Other restoration projects}

An additional 31 projects were identified that did not strictly fall into the other categories (Figure 16). These projects often had multiple stated objectives. For example, a project that may be primarily a shoreline protection project may also create habitat or improve drainage in marsh areas increasingly becoming submerged. Erosion control and beach protection was reported as the primary purpose for 17 shoreline projects, one created a sand berm to preserve dune habitat, the rest were bank stabilization or infrastructure removal (e.g., parking lot removal, end of road restoration) projects. The shoreline projects are spread throughout the bay, although there is a concentration of projects on the Providence 
River, particularly immediately upstream of the river mouth just south of Cominicut Point. Eleven of the projects were described as habitat enhancements. Of these, two were edge restoration projects, and two were grassland projects. One project was simply listed as habitat restoration, another as reef project geared towards finfish and shellfish habitat creation, another as a river restoration project. Removals included three debris removal projects clearing trash from shorelines and one sediment management project. 
Figure 16. Map of Narragansett Bay other restoration projects. The dark green circles are projects described as habitat restoration. The light green circles show the location of shoreline restoration projects.

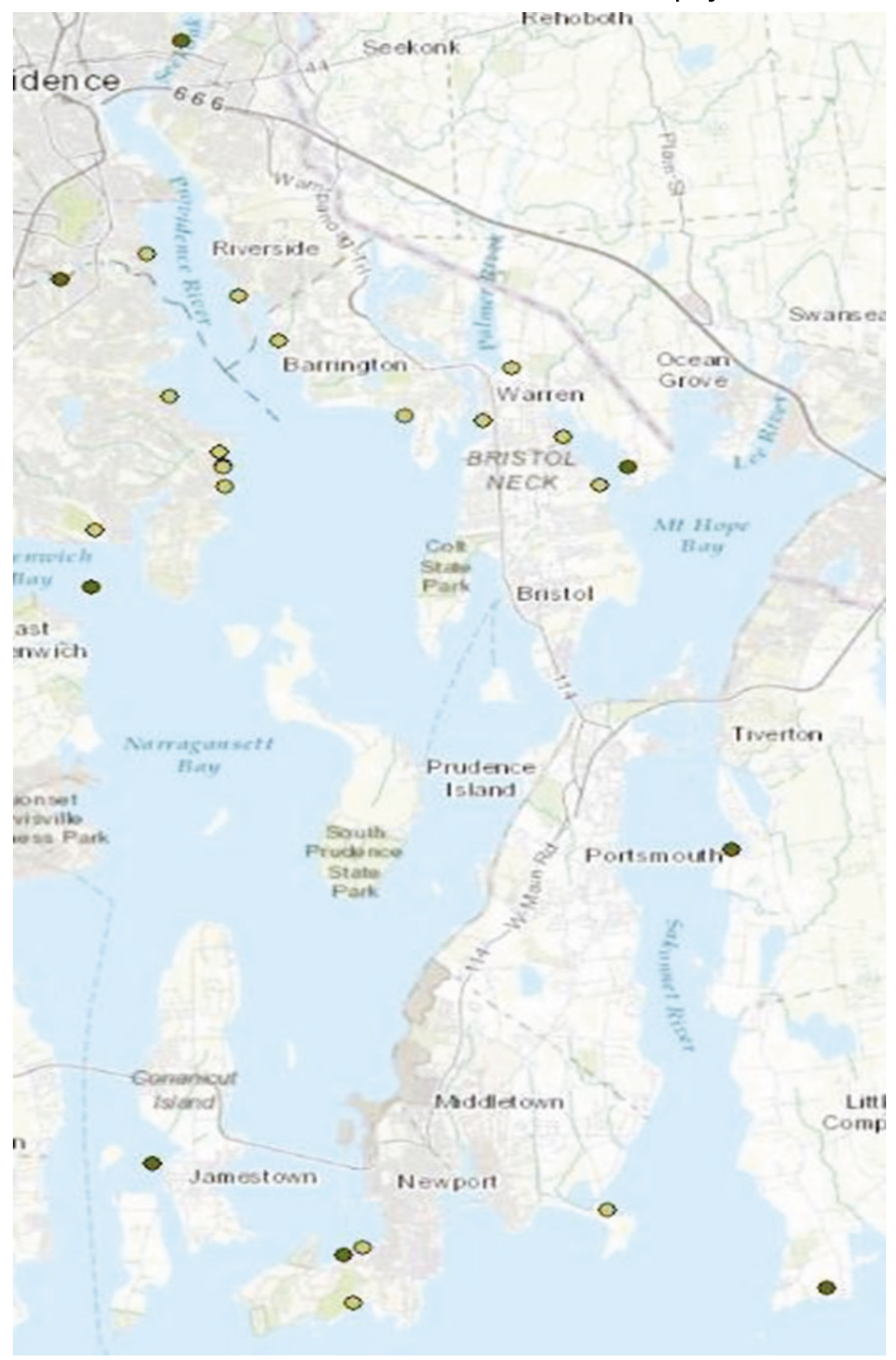




\section{Implications for Restoration Projects}

\subsection{Fish passage}

\subsubsection{Historical conditions and conceptual model}

Inland fisheries have been of great historical importance to the Narragansett Bay. River herring is the oldest inland fishery in the U.S., opening coastal waters to international fishing fleets in the late 1960s resulted in the depletion of these species (NMFS 1989). Dam construction, water quality degradation, and overland erosion has impacted the quality and quantity of accessible spawning habitats (Limberg and Waldman 2009). Prior to the industrial revolution, fish had relatively unimpeded passage from the Bay into 45 runs. Currently, more than 1,000 constructed obstructions leave only 18 of those runs partially accessible (Kutcher 2009).

Conceptually, restoration of fish passage reverts access to the inland habitat and spawning sites for specific species (Figure 17). The historical conditions can be represented as a network of the extent and interconnectedness of all the fish habitat in the Bay. Therefore, the current condition (without restoration) and the restored condition would be considered a subset of that network that the fish can utilize. This conceptualization also allows specification of the extent and connections that are currently possible, given the level of development and utilization that has limited the historical extent. Within this framework, restoration projects are considered by the incremental return of habitat or extent that they provide. This return likely needs to be quantified in non-compensable units such as grams of fish or numbers of fish (many species). Restoration that returns habitat and supports population growth can be removal of physical obstacles (dams), but also improvement of water quality, regeneration of environmental conditions (e.g., water temperature, substrate type, etc.), or re-establishment of natural food sources. 
Figure 17. Conceptual model for consideration of restoration projects. The first network (far left) is a representation of the historical sites, and extent and interactions of fish habitat. Shading in that network represents the current (darker) and currently possible (lighter) extent of the habitat given the encroachment of development. From the current conditions (second from left), restoration adds back sites and connectivity that pushes the system toward the maximum possible given current conditions (far right).

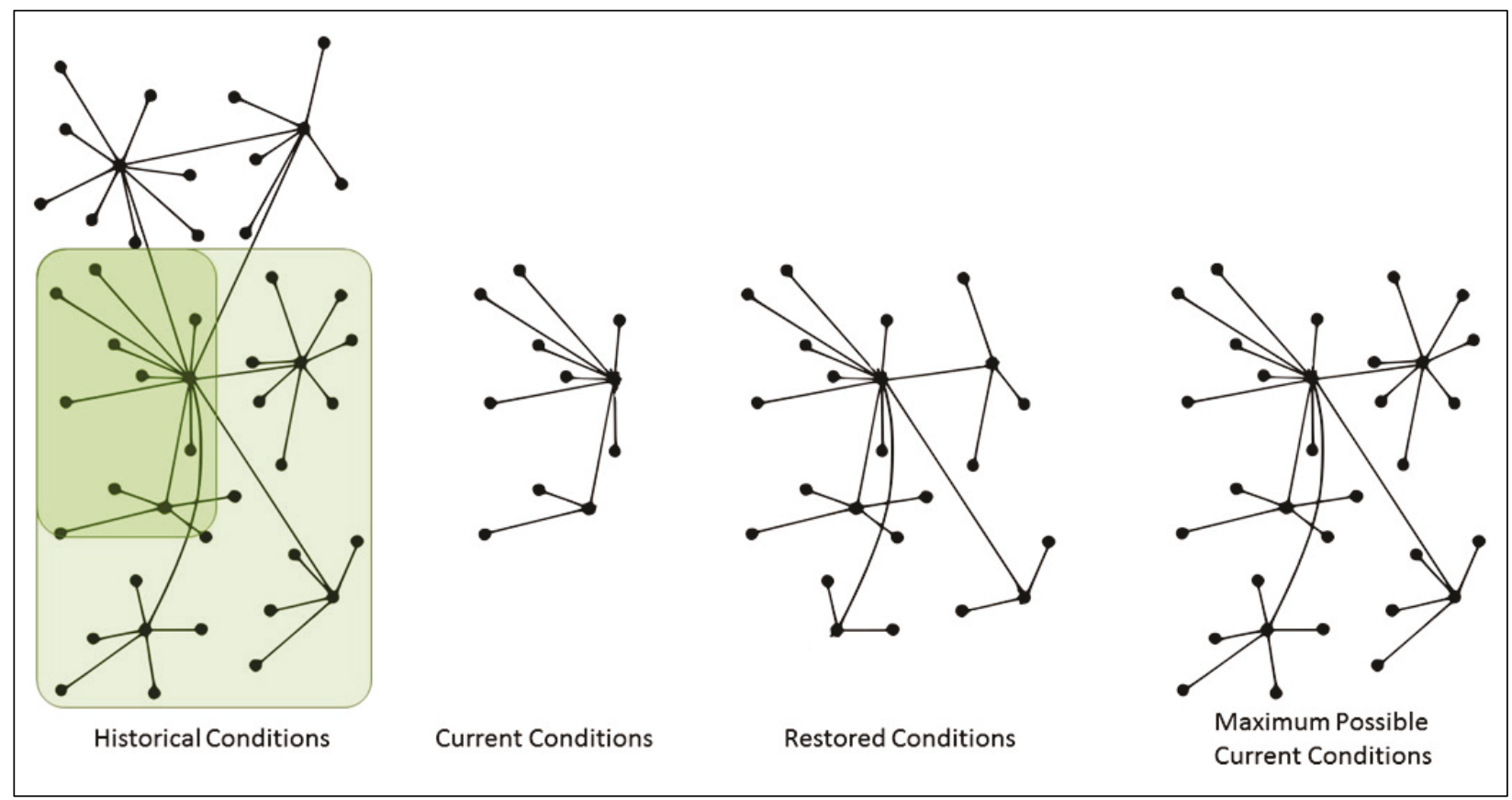

For fish passage in Narragansett Bay, anadromous fish were reported to be plentiful in the late 1800 s (Oviatt et al. 2003). Alewife, shad and smelt were a significant inland fishery at that time. Commercial alewife landings were not reported for any Rhode Island county in 1960. Oviatt et al. (2003) estimates indicated that current yield of all fish landings has dropped six-fold from 1960 to 1999 . The authors also calculate a theoretical current yield for fishery landings based on primary production of 9 grams wet weight per square meter (Oviatt et al. 2003). Counts of the spawning stock of river herring from 2010 to 2016 range from 100,000 to 250,000 fish, this is a substantial reduction. ${ }^{1}$

\subsubsection{Restoration calculations and accomplishments}

The collective efforts to improve fish passage have resulted in more than $800 \mathrm{~km}$ of newly accessible river herring habitat in the Narragansett Bay watershed. The increase in the area of habitat, for each species, can be utilized to estimate how many fish were added to populations as a result of these efforts. Based on a conservative estimate of 9 meters width of area of 
habitat made accessible from the new passage, the increase in the number of alewife and blueback herring in the system can be estimated. Estimations of gains from restoration involve use of specific density models, biomass projections, and approximations derived from other literature. These estimates are useful in determining the relative magnitude on gains for collections of projects. However, they inherently contain uncertainty and errors.

Density models developed by Gibson (1984) predict population from an area without consideration of biological interactions such as competition, predation, and density dependence in the way that population models would. Based on the density models, the increase in alewife is estimated at 3.2 million (following from Gibson 1984). The projection is 2.1 million alewife from linear extrapolation, and 1.7 million alewife from asymptotic extrapolation. A report from the New Hampshire Fish and Game Department indicates that Maine has measured 235 blueback herring per acre of accessible surface water (New Hampshire Fish and Game Department 2011). Based on this estimate, as many as 2.86 million blueback herring may have been added to the population in the Bay. The estimated gain in American shad, 731,000, is based on the Connecticut Department of Environmental Protection (2000) measurement of 60 shad per surface acre, estimates range from 48 (Susquahanna) to 100 (Merrimack) shad per surface acre (Merrimack River Basin 2010). Hall et al. (2012) estimate the biomass of alewife for the Damariscotta River in the Gulf of Maine at 2.5 X $104 \mathrm{~kg} / \mathrm{km}$. Based on this model, and the $350 \mathrm{~km}$ of passage opened, the estimated gain in alewife might be as high as $8,750,000 \mathrm{~kg}$, approximately 42 million spawning sized (230 gram) fish. Analogous estimation rules were not found for eel, salmon, or brook trout population dependencies. Limberg and Waldman (2009) estimated current and historic populations of river herring and shad along the Western Atlantic. Based on the increase in the population estimated here, and the metric tons of fish they report, the restoration efforts may account for a restoration of as much 2.5\% increase of the historic population for alewife and blueback herring, and 7.8\% for American shad in the Western Atlantic.

\subsubsection{System-wide and related benefits}

It is generally accepted in the ecological literature that roughly 10 percent of energy in ecological systems is passed to the next higher trophic level (Lindeman 1942). Applying the 10 percent trophic transfer concept to the increase in river herring and shad production, the completed fish passage 
projects in Narragansett Bay could add as much as 875,000 kg of production to higher tropic levels (e.g., striped bass, bluefish, weakfish).

\subsection{4 "Next step" projects}

Measurement of the potential of next step projects allows identification of sites where barrier removal or fish ladder additions can have a major impact on habitat accessibility. Opening Forge Pond Dam, Cotton Gin Pond Dam, and Robbins Reservoir Dam for fish and eel passage has the potential to add $27-30 \%$ to the population gains that can be attributed to existing fish passage efforts. Evaluation of area upstream of the existing obstruction can provide further insight into the quality of the new habitat.

\subsection{Salt marsh restoration}

\subsubsection{Historical Conditions and Conceptual Model}

Narragansett Bay salt marshes provide habitat for nekton and juvenile fish, sequester sediments and nutrients, and stabilize the coastline from the forces of erosion. Reports indicate that $53 \%$ of the Bay's salt marsh has been destroyed over the last 300 years, and that much of the remaining marsh is degraded (Save the Bay n.d.). The currently impounded marshes have lower salinity, invasive Phragmites, and degraded nekton assemblages (Kutcher 2009). Restoration of salt marsh allows tidal flushing, access to habitat, and slows the spread of Phragmites. The possible extent of marshes currently is changing, potentially decreasing, due to sea level rise and the loss of coastal areas during storms. Although the benefits of additional salt marsh are diverse, one possible measure of the gain may be to consider the grams or numbers of fish added because of a project. Although that representation of the benefits is not complete, it can be aligned with the estimations of gains in anadromous fish.

\subsubsection{Restoration calculations and accomplishments}

The salt marsh restoration projects considered in this study most often result in sites dominated by Phragmites. Restored salt marshes have different, and larger assemblages of marsh species than isolated or Phragmites-dominated marshes. The majority of the marsh restoration projects herein identified rewetting and restoring tidal flushing as their objectives, some others included planting Spartina marsh grass. A typical project may be considered as one that restored tidal flushing through installation of a culvert with some excavation of the channel and some 
planted Spartina. If the existing marsh was reported as the project area, it was assumed that the excavation, rewetting, and replanted area was a relatively small portion of the marsh. For the purpose of calculating gains from these projects, it was conservatively estimated that $10 \%$ of the total 331 ha restored was restored to Spartina and another 10\% was mixed Spartina-Phragmites. Based on density models developed by Gratton and Denno (2005), the number of arthropods in this estimated restoration area would be expected to increase by 313,000 individuals. That same area assumption would also allow for a gain of 11 million nekton individuals following density models from Roman et al. (2002), to include mummichog, minnow, eel, and crabs. Adding together projected gains in the number of fish from these projects, totals an increase of 9.6 million fish.

\subsubsection{System-wide and related benefits}

Applying the 10 percent trophic transfer concept to the increase in salt marsh nekton production, the completed salt marsh restoration projects pass on 10 percent of that production to higher tropic levels (e.g., striped bass, osprey, and black ducks). These salt marsh assemblages support a number of bird species expected to benefit from the restored marsh (Schwartz 2009). Ospreys and black ducks have been noted on a restored Galilee marsh. High salt marshes provide habitat for the threatened salt marsh sparrow. Accurately accounting for the benefits generated from restored salt marsh is limited by the availability of data. However, numerous benefits are expected either from newly created marsh habitat, or from areas that were Phragmites dominated and now include native marsh grass and tidal influence. If, for example, all 818 acres of salt marsh projects were new (not converted) marsh, that area could sequester an additional $2.7 \mathrm{~kg}$ of nitrogen $(\mathrm{N})$ each day. That estimate is based on the MA DER measurement of $\mathrm{N}$ sequestration at Muddy Creek. For that 55 acre restoration of tidal flushing, it was found to sequester an additional $0.18 \mathrm{~kg} \mathrm{~N} /$ day after the project was completed (ICF International 2014). The actual sequestration of $\mathrm{N}$ would depend on the loading rate and area, as well as the flow rate and vegetation on the marsh (Davis et al 2004). Culvert and fill removals were not exposed to tidal water, and could not remove $\mathrm{N}$ from the estuary, however, they may sequester $\mathrm{N}$ from runoff preventing it from entering the bay. If the restored area was created marsh, it is likely to provide benefits in terms of increased sediment retention. The amount of sediment retention in marshes varies greatly from site to site with flow rate and volumes as well as the amount and types of suspended solids. Modeling performed by the 
USACE Norfolk District (2013) revealed that the 818 acres at that site would be expected to retain an additional nine million $\mathrm{kg}$ of sediment annually (assuming established vegetation, constant density through the winter, and a high rate of total suspended solids in the inflow).

The carbon footprint of a salt marsh restoration is a complex calculation as it involves the carbon released (emissions) as a site is altered from dry to wet, or as sediments or plants are removed or added. Calculators for carbon emissions (Blue Carbon Calculator 2016) allow the estimation of the tons of carbon per year from extraction, drainage, rewetting, and remaining wetlands. Negative values for emissions indicate a net sequestration each year for that category of wetland. For example, in Table 4, an assumption has been made that $10 \%$ of the 331 ha was Phragmites that was rewet following restoration, $10 \%$ was rewet dominated by other species, $10 \%$ was drained, and $25 \%$ was extracted. The remaining $45 \%$ was assumed to be unchanged, Phragmites-dominated marsh. Given these assumptions, the restoration example can be expected to emit 28,000 tons of carbon in the first year and more than 200 tons of carbon in other years. The carbon emissions is largely due to the drained portion of marsh. The emissions are a cost of the sediment and foliage removal process for invasive species control. Another carbon calculation can be made based in the difference the amounts and the carbon sequestration rate for different types of salt marsh habitat. For this calculation, the types of marsh are high/salt panne, low, tidal/mudflat/channel, Phragmites dominates, freshwater wetland, filled upland, coastal grass land, and subtidal. The pre-and post-restoration area in each category is compared to determine how much more metric tons of carbon dioxide equivalents $\left(\mathrm{MTCO}_{2} \mathrm{e}\right)$ will be sequestered each year following restoration. Based on a similar breakdown in marsh categories, and using the carbon sequestration parameters developed for Quincy Marsh (ICF International 2014), the restoration projects are expected to average an additional sequestration of more than $216 \mathrm{MTCO}_{2} \mathrm{e}$ each year.

Table 5. Estimated carbon emissions, based on categorization.

\begin{tabular}{|l|l|l|l|l|}
\hline Category & Percent & Area (ha) & Amount & Unit \\
\hline Remaining & 0.45 & 149 & 13.7 & tons of carbon/yr \\
\hline Rewetting - Phragmites & 0.1 & 33 & -25.3 & tons of carbon/yr \\
\hline Rewetting & 0.1 & 33 & -30.1 & tons of carbon/yr \\
\hline Drained & 0.1 & 33 & 261.5 & tons of carbon/yr \\
\hline Extraction & 0.25 & 93 & 28137.8 & tons of carbon \\
\hline Sum & 1.0 & 331 & $\mathbf{2 8 3 5 7 . 6}$ & tons \\
\hline
\end{tabular}




\subsection{Eelgrass restoration}

\subsubsection{Historical conditions and conceptual model}

Prior to the 1930s, eelgrass was abundant in Narragansett Bay and all along the Eastern Seaboard (Chaffee et al. 2012). However, during the 1930 a wasting disease related to slime mold, Labryinthula zosterae, resulted in the death of approximately 90 percent of eelgrass across the Eastern Seaboard. While eelgrass habitat started to rebound following the mass die off, worsening water quality has led to a decline in eelgrass habitat since mid-1950s. Eel grass support fisheries, and shellfisheries, as a highly productive habitat for developing organisms. Many of the eel grass efforts included in the present analysis were sustainable for a period of several years, but not over longer time periods. Generally, these efforts demonstrate that transplanting eelgrass is not sufficient to ensure success. If the water quality and depth is adequate for development of eelgrass beds, the grass will colonize without transplantation. The limitation for the extent of eelgrass bed currently is, therefore, based on water quality and the changing water depth of parts of the bay. This understanding has important implications for eelgrass restoration projects, this effort may be better spent on improvement of water quality or supporting natural expansion of beds. The benefit statement for the eelgrass projects have included their contribution to the understanding of water conditions and methods for support of eelgrass beds development. However, the project locations themselves are unlikely to sustain significant populations of fish for consideration benefits accounted for in "non-compensable unit" in order to compile these efforts with others in the study region.

\subsubsection{Restoration calculations and accomplishments}

Eelgrass restoration efforts have been ongoing in Narragansett Bay and coastal salt ponds for over ten years. While none of the test sites in the northern portion of Narragansett Bay, north of Prudence Island, have survived, there has been some successes in the southern portion of the bay (Chaffee et al. 2012). In 2012 it was estimated that there were a total of 231 ha between the Sakonnet River, Narragansett Bay, and East and West Passages of Narragansett Bay (Bradley et al. 2012). Since 2002, the transplant site on the west side of Prudence Island has had eelgrass transplant survival rates between 50 to 60 percent each year. Moreover, with the exception of eelgrass transplanted in 2003, each surviving transplant group has expanded in subsequent years. In 2005, planting 
began at Coggeshall Point in Portsmouth. Save The Bay's five year monitoring program has shown that there have been consistent survival rates between 60 and 80 percent, and that the site is also rapidly expanding. Hog Island received its first eelgrass transplants in 2007 and has had survival rates ranging between 65 and 80 percent each year.

One of the most successful transplant sites in 2002, Fogland Point in Tiverton, failed the following year. By 2004 none of the planted eelgrass remained at the site. In 2004, a transplant site at Sauga Point, had the highest survival rate of 68 percent. Monitoring between 2005 and 2007 saw a steady decline in current and previous eelgrass transplants, and 2008 monitoring found that the transplants of 2007 completely failed. Although Fogland Point and Sauga Point had early success, unfavorable long-term conditions proved to make these sites unsuitable. Fogland Point lost eelgrass primarily to ice scour and shading from macroalgae, Sauga Point's failure is accredited primarily to crab predation.

\subsection{Shellfish restoration}

\subsubsection{Historical conditions and conceptual model}

Historically, Narragansett Bay had reported commercial fisheries for softshelled clam, cultured oyster, and scallop, all of these have disappeared from the bay (Ovaitt et al. 2003). Catches were reported in the 50,000 $500,000 \mathrm{~kg}$ wet weight annually in the late 1800 s for these species. In 1960, no soft-shelled clam or scallop, and few oysters, were reported in the landings. The general trend is the loss of shellfish from the area with lobsters being the reported exception. Ovaitt et al (2003) report that the lobster catch has increased fivefold between 1960 and 2000, although the catch per unit effort decreased over that time. Possible recovery of shellfish populations will depend on water temperature and nutrient loading, both of these can impact growth and settlement. In fact, increasing water temperature and decreased predation from cap, scup, and others has been cited as the possible reason behind the increasing lobster catch (Ovaitt et al. 2003 and references therein). This return on investment in shellfish project is difficult to quantify in numbers or grams of fish, because many of the restoration projects analyzed utilized seeding and transplant methods. 


\subsubsection{Restoration calculations and accomplishments}

The gains or recovery of shellfish populations due to the efforts in Narragansett Bay are unknown. A 2010 scallop survey by Save the Bay (Save the Bay, n.d.) found a scallop density in samples from Narragansett Bay of 0.002 scallops $/ \mathrm{m}^{2}$. This reported density is fourteen times lower than the estimated density in Point Judith Pond for the same time. Recruitment and survival of different species depend on a suite of factors, but a small increase in either parameters is likely to have substantial impacts of different populations. The 2016 Shellfish Sector Management Plan (RI DEM 2016) reports commercial landing and dredging surveys for quahogs, softshell clam, and whelk in Rhode Island. Commercially landed weight of quahogs has been increasing since a 2009 low point, but amounts have been down for the last two years. Soft-shell landings are down sharply since 2007, with little extremely low catch per unit effort since 2012.

Based on the number of clams and oysters added, some water quality benefits can be attributed to the restoration efforts in Narragansett Bay. With a conservative assumption of 37.85 liters (L) of bay water filtered each day by one clam, the seeded clams in the bay are anticipated to filter $492,000,000 \mathrm{~L}$ of water daily. Site with active oysters are estimated to remove twice as much nitrogen as sediment alone (Humphries, et al. 2016). The reported restoration efforts encompassed at least 83.3 ha of shellfish project (five of the 43 projects). Assuming active oysters were added, and apply the measured rate of denitrification of oysters measured in bare sediment ( $24.4 \pm 10.1 \mu \mathrm{mol} \mathrm{N}-\mathrm{N} \mathrm{m}-2 \mathrm{~h}-1$; Humphries et al. 2016), then the active oysters would be responsible for $20.3 \mathrm{~mol} \mathrm{~N}_{2}-\mathrm{N}$ $\mathrm{m}-2 \mathrm{~h}-1$ removal. Note, however, the number of individuals added will be different from the number surviving to produce these benefits.

\subsection{Other restoration projects}

The other identified restoration projects aimed to enhance shoreline protection or drainage or to improve habitat. The enhancement in shoreline protection is unmeasured. The need for shoreline protection is evidenced by the reported rise in sea level of more than 0.1778 meters in Providence since the 1930s (Emery 2013). Rising sea level requires efforts to improve drainage in existing salt marsh to help abate their loss (West 2014). Further, protecting shorelines from erosion may reduce suspended solids and sedimentation which could improve water quality. 


\section{Discussion}

The types of restoration projects identified here contribute to the ecosystem functions of the Narragansett Bay. Fish passage allows for the movement of anadromous fish to spawning habitat, enhancing their local populations and supporting the productivity of the bay and riverine habitat. Salt marsh restoration provides habitat and shelter for juvenile and migrating fish, feeding and nesting ground for birds, and highly productive habitat for nekton. Marshes sequester carbon and nitrogen, and accumulate sediment allowing for improved water quality in the estuary and bay. Eel grass restoration provides import benthic habitat for fish and crustaceans, sequester nutrients, and improve water quality in the estuary. Shellfish restoration supports commercial and recreational harvesting and provides substantial filtering and nutrient removal from bay waters. Other restoration, including shoreline protection, prevents erosion and deterioration, promotes public access, and serves as a buffer against rising sea levels.

Restoration efforts to improve fish passage between 1999 and 2016 have resulted in hundreds of kilometers of newly accessible aquatic and riverine habitat for alewife and blueback herring, American shad, and American eel including brook trout. Based on the present analysis, the restored habitat was considered a measureable cumulative positive impact on the populations of river herring in the Narragansett Bay watershed. The spatial analysis identified several next step restoration projects that have the potential to contribute additional quality habitat. Consideration should be given to the passability of fish ladders, and their relative efficiency for different species, in the design of future projects.

Marsh restoration and creation provides benefits in the broad categories of biological productivity and species assemblages, water quality, and carbon budgets. In order to quantify the water quality and carbon budget changes from these projects, detailed project descriptions would be required that include area measurements for drained and rewetted regions, shoreline measurements, and the rate and amount of solids in overland water flow. The potential for interactions among these projects would require an understanding of species utilizations and movement between projects. Although the mid-Atlantic coastal region has successfully restored salt marshes for shoreline protection, the erosional regime in the Narragansett Bay makes marshes less effective for shoreline protection due to large 
fetch, narrow and rocky intertidal zones, and steep offshore bathymetry (Save the Bay 2013). The restoration of these marshes does help maintain a buffer between the ocean and human settlements, providing continued community protection, but the shoreline itself is still susceptible. Marshes with sills and other hardening features can be implemented for erosion protection, but these are specifically designed living shorelines for this purpose and are not necessarily highly valued habitat features. Full information about all of the projects has not been obtained, however, the total improvement to the Bay-wide marshes can be estimated. On one hand, if all 818 project acres represent newly created marsh, this indicates a $28 \%$ gain in overall marsh area in the Bay. On the other hand, if all projects instead represent restoration of Phragmites-impacted marsh to Spartina marsh, it would indicate restoration of $40 \%$ of the previouslyexisting degraded marsh. In reality, the projects likely include a combination of both types of projects, leading to a lower, but still significant contribution to both goals. The projects, even in isolation, enhanced salt marsh productivity in nekton nursery habitat for marine fishes. Coastal marshes are threatened by sea level rise and development, as well as the resulting changes in water quality.

Impaired water quality contributing to the decline in eelgrass habitat and its inability to recolonize stems from point sources such as septic systems and waste water treatment plant discharges, and other nonpoint sources such as polluted urban runoff loaded with lawn fertilizer. Eelgrass survival requires clear water, so increases in water turbidity can limit the spread of eelgrass and lead to plant death (Chaffee et al. 2012). Increased water temperatures which are tied to climate change are also a major issue, as warmer water causes eelgrass to stop producing seeds. Over the last 30 years the water temperature of Narragansett Bay has increased $2^{\circ} \mathrm{F}$ (Save the Bay n.d.). To compound issues, poor water quality from pollution, increased water temperature, and increased salinity increases susceptibility of eel grass to wasting disease (Chaffee et al. 2012). Tied to water quality is water flow. Inadequate flushing of coves and creeks create stagnant conditions where nutrients collect and which promote the growth of algae. Dense mats of algae shade out and can kill eelgrass. Decaying algal blooms sink to the bottom of the water column and result in low oxygen levels that stress and kill marine life (Raposa and Weber 2009).

Eelgrass is a food source for many marine creatures including waterfowl such as brant and Canada geese, sea slugs, and green turtles. Crustaceans 
such as blue crabs, long-clawed hermit crabs, and flat-clawed hermit crabs are known to feed on eelgrass seeds (SeagrassLI 2012). While these marine animals consume eelgrass, they are not known to degrade the eelgrass habitat. Conversely, in addition to laying waste to shellfish populations, European green crabs can transform dense stands of intertidal eelgrass into mudflats over the course of just a few years. Green crabs uproot, snip, and shred the bases of eelgrass causing them to drift away in house-size rafts (Beem 2014). Green crabs have been documented in Rhode Island waters since 1880 , and tolerate a wide range of environmental temperatures (USGS 2018; University of Rhode Island n.d.).

The future of these restoration efforts may be to better understand the water quality and sea level rise implications for the selection and maintenance of sites for transplanting eel grass. The benefits of eel grass are numerous and documented (Chaffee et al. 2012). In New England eel grass provides habitat for an estimated forty fish and nine invertebrate species. Eelgrass beds provide cover for bay scallops, quahogs, blue crabs, lobsters, and seahorse. Tautog and other fish lay eggs on the surface of eelgrass leaves and starfish, snails, mussels, and others attach themselves to eelgrass. Certain waterfowl such as brant feed on eelgrass. Decaying eel grass leaves provide organic matter for microorganisms. In addition to the habitat benefits of eel grass, eel grass beds dampen wave energy, stabilize sediments, and filter nutrients in the water column. Seagrasses, such as eelgrass, are thought to store twice as much carbon per unit as temperate and tropical forests. Seagrasses have been shown to provide billions of dollars of ecosystem services globally, in terms of nutrient sequestration and productivity (Waycott et al. 2009).

The other restoration projects evaluated can be broadly classified targeting shoreline protection, drainage enhancement or habitat improvement. Recent reports indicate that storm events and sea level rise result in punctuated loss of shoreline, and that living shoreline efforts are unlikely to provide long-term sustained protection from these larger threats (Save the Bay, 2013). Although collectively, such projects may not abate storm surge or prevent salt water inundation, the projects are anticipated to enhance local infrastructure protection and provide a useful short- or medium-term buffer as sea level rises until more permanent restoration efforts can be designed and implemented. Local habitat improvement has the potential provide key corridors and linkages with regional essential habitat. 
Restoration efforts to date in Narragansett Bay demonstrably enhance other ecosystem services provided, although these are difficult to measure and quantify and not included in the scope of the present study. Specifically, these efforts should yield substantive benefits both in education and research value and also in community engagement. Partnerships with local universities support the understanding of complex estuarine systems and the cultivation of a next generation of scientists who have a deep understanding of the region. Restoration also is a conduit to community engagement in their watershed and environment. Anecdotal information support that fish counts, surveys, and clean-up projects contribute to a sense of place and ownership that enhances community cohesion and pride. Volunteers provide fish counts at Atlantic Mills which has resulted in community ties to the herring restoration effort. ${ }^{1}$ That sense of community is associated with efforts to enhance community access to and utilization of the waterfront. The area now has a boat launch, regular use by kayakers, and a bike camp associated with the path. Volunteers support not only fish counts and sampling but also clean-up efforts. The environmental and habitat benefits are, therefore, likely to be just one class of services provided by these collective restoration efforts. Reported benefits include public access and enjoyment of restored sites.

The means to quantitatively assess the overall benefits to the ecosystem are limited and require additional data to evaluate. Different approaches that might be taken include historical restoration, threshold evaluation, release of limiting habitat factors, and sustainable population assessments. Comparison of the restoration acreage or mileage to historic totals would lend some perspective. Recreation of the historic areas might be possible from elevation and research into documents and drawing. However, the historical data is not readily available. Alternatively, thresholds for restoration features that have been determined for the region can be used as benchmarks for assessment of collective restoration gains. Schueler et al. (2009) review found that 10-15\% imperviousness of a watershed is related to a decline in stream quality. However, that type of concrete and measurable threshold is not available for many indicators. Alternatively, habitat features that serve as limiting factors in the life histories of specific species can be examined for the change post-remediation. For example, the distance over which water velocity is conducive to alewife spawning may be a feature that limits the amount of spawning for this species (Burdick and

\footnotetext{
1 Joseph Bachand, Rhode Island Natural Resources Conservation Service - USDA; pers. comm; May/2016
} 
Hightower 2006). Determining the extent of flow conducive to alewife spawning pre- and post-restoration could provide a magnitude of benefits for this species. Escapement goals for the anadromous fish on the impacted rivers could be used as an estimate of changes in the robustness of those species. Calculations and measurements of populations over years could provide a source information about the target population necessary for support or sustainment of a species. Current counts from several of these rivers for alewife provide some initial information that could support population and escapement analyses. While each of these approaches is limited by currently available data, they provide an avenue for future research and the foundation for further analyses.

Ideally, a mechanism could be created to evaluate, or even value, the benefits realized from restoration at the watershed scale. Each class of benefit from each type of restoration would need to be combined in an index function. Such a function would allow calculation of with and without project value. This relative change allows the direct comparison of individual projects or the change in condition over time. Some attempts have been made to develop this type of large-scale functional index. Hydrogeomorphic models (HGM) produce an index score of the functional capacity for a specific class of wetland through measurement of the processes that the wetland performs (ERDC HGM Webpage 2017). A series of sub-models are used to assess the capacity of each function. In order to implement a HGM, a regional guide has to be developed for the wetland type providing a measurement protocol. Additionally, a set of standard sites (pristine to impacted) need to evaluated as a kind of calibration of the HGM. The Index of Biological Integrity (IBI) is a model function based on the species diversity and abundance in the local community that allows relative evaluation of the impact of a disturbance. Model development for an IBI also requires calibration of a range of locations under a variety of conditions. Evaluation of a site by IBI requires repeated sampling (spatial and temporal) and identification by trained professionals to identify organisms. An estuarine biologic index (EBI) was been developed and implemented in near-by Cape Cod and Buzzards Bay (Hughes et al 2002). Implementation in Narragansett Bay would require recalibration and sampling. In addition, without the sampling before the restoration work was conducted, no conclusions could be drawn about the change in condition associated with the projects that were included in the present analysis. The Multi-scale Assessment of Watershed Impacts (MAWI) is a data-intensive model that can be used to assess the change in 
project condition through assessment of homogenous wetland units using other models such as HGM, IBI, etc. (Smith and Klimas 2013). The unit assessments, each compared to a reference condition, can be complied into a baseline evaluation. This secondary evaluation can only be applied if the primary models and baseline data are available. Another relevant index function is the Ocean Health Index (OHI). Halpern et al. (2012) developed the $\mathrm{OHI}$ "comprising ten diverse public goals for a healthy coupled human-ocean system." Measurement of the relative performance on each of the goals is based on an established set of metrics. Regional and baseline assessments are necessary to evaluate the effect of change over time and with the addition or removal of a specific habitat feature. Furthermore, the OHI goals are largely removed from (although dependent on) the restored ecosystem function that are the objective of the present study. Development of a large-scale index function to evaluate benefits is an area of research that would yield a reproducible metric to measure realized gains from a set of restoration projects.

The potential interactions between these projects has not been measured, although research indicates that there connectivity between these different types of wetland habitats (Meynecke, Lee and Duke 2008). However, the ways in which these different types of projects can influence each other's benefits can be postulated (Figure 18). The amount of coastal nursery habitat has been shown to influence the stock size for predatory fish species (Sundblad et al. 2014). Consider that fish passage requires specific water flow over obstacles, and that water volumes that can be altered by the stream edge and adjacent marsh habitats which influence the volume of water in the stream channel. Dam removal often increases the area of wetland and can influence sedimentation closer to the estuary. The success of anadromous river herring passage projects produce fish populations that are connected to restored salt marshes by their need for cover on their way back out to the bay and ocean. They also benefit from salt marsh productivity as a productive habitat that can provide food sources. The success of fish passage and shellfish restoration projects are both dependent on water quality in the estuary, as it influences the health of both species. Water filtration by shellfish can positivity that water quality. Further, fish will feed on shellfish larvae. Fish passage project are also supported by eelgrass restoration. Eel grass provide essential habitat for small and juvenile fish as they return to the estuary. Salt marsh restoration projects and shellfish restorations projects also provide potential interactions. Salt marshes retain sediments and nutrients, improving water quality for 
shellfish. Some crustacean live within marshes, and provide essential aeration for marsh grasses in digging burrows. The productivity provided by marsh habitat increases the numbers of these crustaceans. Eel grass success and shellfish restoration are both dependent on water quality which may be improved through the increase in salt marsh habitat. The amount of eel grass could, in turn, influence the productivity of nearby salt marsh and the success of shellfish restoration by providing additional shelter for small animals and recruitment for larvae.

Figure 18. Conceptual interactions between the types of restoration projects. Likely interactions between fish passage and salt marsh projects (1) are creation of shelter and productive feeding area for hatched fish on their way back to the bay. Between fish passage and shellfish restoration (2) interactions are water quality, water filtration, and prey availability. Fish passage project and eelgrass restoration (3) are linked through the juvenile fish habitat in the estuary. Salt marsh restoration and shellfish projects (4) interact through retention of sediments and nutrients and improved water quality, and physical support of marsh grass. Salt marshes and shellfish restoration (5) are both dependent on water quality. Eel grass and salt marsh restoration (6) both provide additional shelter for small animals and recruitment for larvae.

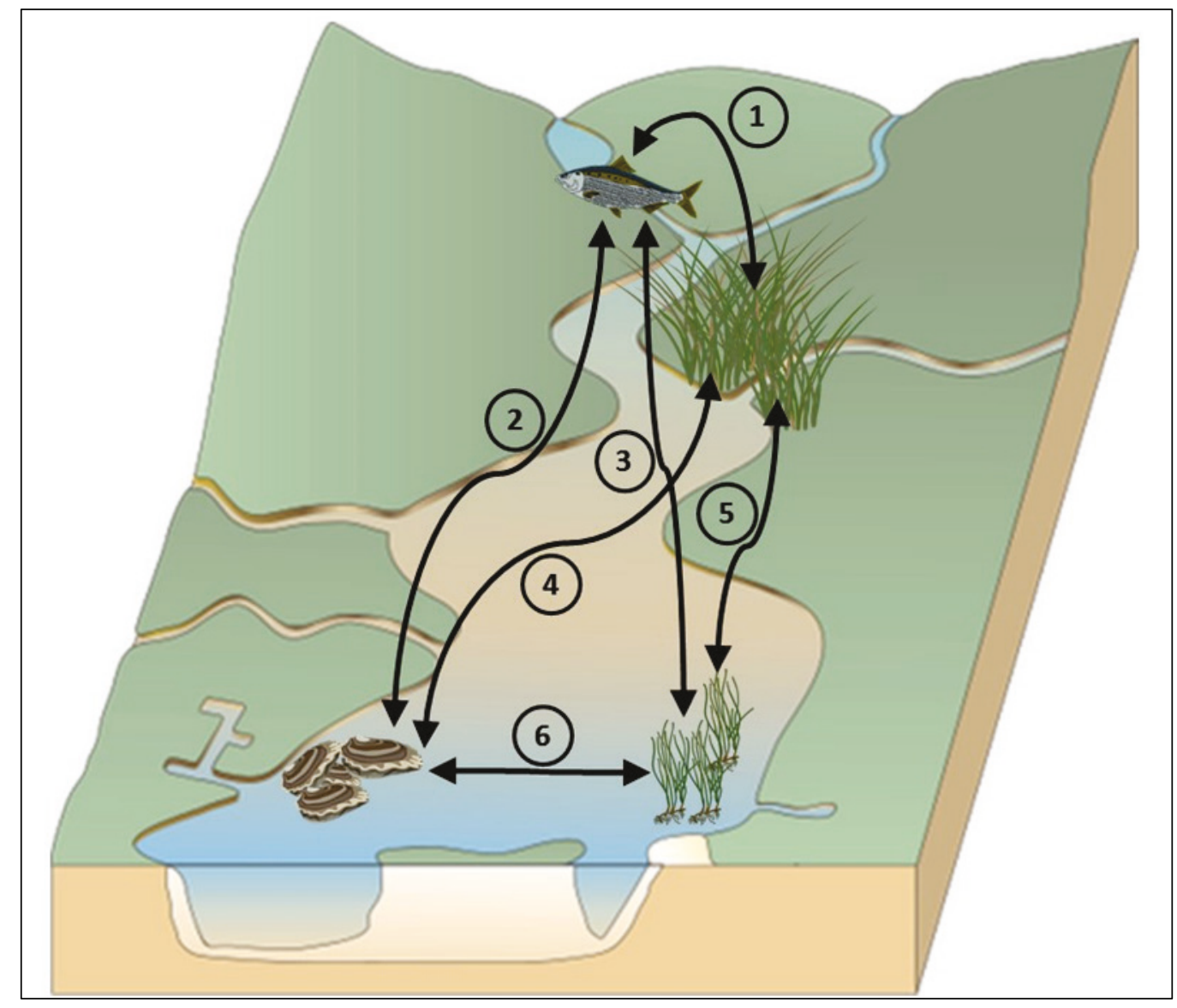


The catalogue of the restoration effort, as well as the quantification of the projects, their sizes and types provide an opportunity to report on the collective impacts of restoration in the area. From the project information collected, it can be inferred that a range of benefits including changes in fish population and carbon sequestration can be achieved. However, the lack of available data makes it impossible to determine the extent of change in water quality, fish and shellfish populations, or other ecosystem services. Measurement of these factors, at the project and bay levels, might allow future characterization of the accrued benefits from these restoration projects and infer the additive features inherent in multiple restoration projects. 


\section{Summary}

This project analyzed over 300 completed restoration projects in the Narragansett Bay, RI watershed to map and quantify the additive benefits associated with their implementation since 1999. Restoration projects analyzed included fish passage, dam removal, salt marsh restoration, shellfish restorations, eelgrass projects, and other restoration projects. The present analyses demonstrated the potential cumulative benefits of the restoration investments over time. The present project collected the effects of multiple discrete aquatic ecosystem restoration projects in order to align the benefits, in terms of increasing numbers of fish. Based on gains in terms of these units, the projects can be considered collectively as a group. The present project underscored the need to quantify and document restoration efforts at the project scale. This post-project analysis of the additive benefits of multiple aquatic restoration projects at the watershed scale quantified and demonstrated the added function and value provided by completed and potential future projects. Future research could include similar analyses being applied at other watersheds and the cumulative combined benefits across watersheds, and reducing data gaps and uncertainties associated with quantifying the education and recreation benefits, and success of various fish passage restoration projects. 


\section{References}

Beem, E. A. 2014. The green crab invasion: Will Carcinus maenas destroy Maine's $\$ 15$ million soft-shell clam industry? Down East. http://downeast.com/green-crabinvasion/.

Bernhardt E. S., M. A. Palmer, J. D. Allan, G. Alexander, K. Barnas, S. Brooks, J. Carr, S. Clayton, C. Dahm, J. Follstad-Shah, D. Galat, S. Gloss, P. Goodwin, D. Hart, B. Hassett, R. Jenkinson, S. Katz, G. M. Kondolf, P. S. Lake, R. Lave, J. L. Meyer, T. K. O'Donnell, L. Pagano, B. Powell, E. Sudduth. 2005. Synthesizing U.S. river restoration efforts. Science 308(5722): 636-637. doi: 10.1126/science.1109769.

Blue Carbon Calculator. 2016. Blue carbon calculator. Springfield, MA: Commonwealth of Massachusetts. http://www.mass.gov/eea/agencies/dfg/der/about-us/blue-carboncalculator.html.

Bradley, M., R. Hudson, M. C. Ekberg, K. Raposa, and A. MacLachlan. 2013. 2012 Mapping submerged aquatic vegetation (SAV) in Rhode Island coastal waters. https://www.researchgate.net/profile/Kenneth_Raposa/publication/283721050_2012_Mappi ng_Submerged_Aquatic_Vegetation_SAV_in_Rhode_Island_Coastal_Waters/links/5644c7260 8ae9f9c13e57756/2012-Mapping-Submerged-Aquatic-Vegetation-SAV-in-Rhode-IslandCoastal-Waters.pdf.

Burdick, S. M. and J. E. Hightower. 2006. Distribution of spawning activity by anadromous fishes in an Atlantic slope drainage after removal of a low-head dam. Transactions of the American Fisheries Society 135(5):1290-1300. https://doi.org/10.1577/T05-190.1

Butzeck, C., A. Eschenbach, A. Gröngröft, K. Hansen, S. Nolte, and K. Jensen. 2015. Sediment deposition and accretion rates in tidal marshes are highly variable along estuarine salinity and flooding gradients. Estuaries and Coasts 38(2):434450 .

Chaffee, C., W. Ferguson, and M. C. Ekberg. 2012. Salt marsh restoration in Rhode Island. In C. T. Roman and D. M. Burdick (eds) Tidal Marsh Restoration. The Science and Practice of Ecological Restoration. Washington, DC: Island Press. 157-164.https://doi.org/10.5822/978-1-61091-229-7_9.

Davis, J. L., B. Nowicki, and C. Wigand. 2004. Denitrification in fringing salt marshes of Narragansett Bay, Rhode Island, USA. Wetlands 24(4):870-878. https://doi.org/10.1672/0277-5212(2004)024[0870:DIFSM0]2.0.C0;2.

Emery, C. E. 2013. Politifact: Rhode Island coastal resources geologist says sea level has risen roughly 10 inches since 1930 . http://www.politifact.com/rhodeisland/statements/2013/feb/08/janet-freedman/rhode-island-coastal-resources-geologistsays-sea- $/$.

Engineer Research and Development Center - Hydrogeomorphic (ERDC - HGM). 2017. Hydrogeomorphic approach for assessing wetlands. https://wetlands.el.erdc.dren.mil/hgmhp.html. 
Gibson, M. R. 1984. On the relationship between stock size and production area in anadromous alewives. Research Reference Document 84/2. Providence, RI: R.I. Department of Environmental Management: Division of Fish and Wildlife.

Gratton, C., and R. F. Denno. 2005. Restoration of arthropod assemblages in a Spartina salt marsh following removal of the invasive plant Phragmites australis. Restoration Ecology 13(2):358-372. https://doi.org/10.1111/i.1526100X.2005.00045.x.

Gold, A. J., K. Addy, A. Morrison, and M. Simpson. 2016. Will dam removal increase nitrogen flux to estuaries? Water 8.11:522. doi:10.3390/w8110522.

Hall, C. J., A. Jordaan. and M. G. Frisk. 2012. Centuries of anadromous forage fish loss: consequences for ecosystem connectivity and productivity. BioScience 62(8):723-731.https://doi.org/10.1525/bio.2012.62.8.5.

Hughes, J. E., L. A. Deegan, M. J. Weaver, and J. E. Costa. 2002. Regional application of an index of estuarine biotic integrity based on fish communities. Estuaries and Coasts 25(2):250-263. https://doi.org/10.1007/BF02691312.

Hughes, R. M., P. R. Kaufmann, and M. H. Weber. 2011. National and regional comparisons between Strahler order and stream size. Journal of the North American Benthological Society 30(1):103-121. https://doi.org/10.1899/09-174.1.

Humphries, A. T., S. G. Ayvazian, J. C. Carey, B. T. Hancock, S. Grabbert, D. Cobb, C. J. Strobel, and R. W. Fulweiler. 2016. Directly measured denitrification reveals oyster aquaculture and restored oyster reefs remove nitrogen at comparable high rates. Frontiers in Marine Science 12 May 2016. https://doi.org/10.3389/fmars.2016.00074.

ICF International. 2014. Estimates of ecosystem service values from ecological restoration projects in Massachusetts. Commonwealth of Massachusetts Department of Fish \& Game and Massachusetts Division of Ecological Restoration.https://www.mass.gov/files/documents/2016/08/ob/eco-services-full-mader.pdf.

Kutcher, T. E. 2009. Human impacts on Narragansett Bay. In: K. B. Raposa, and M. L. Schwartz (eds). An ecological profile of the Narragansett Bay National Estuarine Research Reserve. Narragansett, RI: Rhode Island Sea Grant.

LatLong.net (n.d.) Get latitude and longitude. Accessed 13 September 2018. http://www.latlong.net/.

Limburg, K. E., and J. R. Waldman. 2009. Dramatic declines in North Atlantic diadromous fishes. BioScience, 59(11):955-965. https://doi.org/10.1525/bio.2009.59.11.7.

Lindeman, R. L. 1942. The trophic-dynamic aspect of ecology. Ecology 23(4):399-417. https://doi.org/10.2307/1930126.

Long Island's Seagrass Conservation. 2012. Grazers. Cornell University Cooperative Extension of Suffolk County. Accessed 13 September 2018. http://www.seagrassli.org/ecology/fauna_flora/grazers.html. 
Massachusetts Geographic Information Systems (MASSGIS) (n.d.). MASSGIS data layers. Accessed on 13 September 2018. http://www.mass.gov/anf/research-and-tech/it-servand-support/application-serv/office-of-geographic-informationmassgis/datalayers/layerlist.html.

Merrimack River Basin. 2010. A plan for restoration of American shad Merrimack River watershed. Technical Committee for Anadromous Fishery Management of the Merrimack River Basin. https://www3.epa.gov/region1/npdes/merrimackstation/pdfs/ar/AR-96.pdf.

Meynecke, J.-O., S. Y. Lee, and N. C. Duke. 2008. Linking spatial metrics and fish catch reveals the importance of coastal wetland connectivity to inshore fisheries in Queensland, Australia. Biological Conservation 141(4):981-996. https://doi.org/10.1016/i.biocon.2008.01.018.

New Hampshire Fish and Game Department. 2011. New Hampshire ASMFC River Herring Sustainable Fishing Plan. http://www.asmfc.org/uploads/file/NH_RiverHerring_SFMP.pdf.

Noonan, M. J., J. W. Grant, and C. D. Jackson. 2012. A quantitative assessment of fish passage efficiency. Fish and Fisheries 13(4):450-464. https://doi.org/10.1111/i.1467-2979.2011.00445.x.

Oviatt, C., S. Olsen, M. Andrews, J. Collie, T. Lynch, and K. Raposa. 2003. A century of fishing and fish fluctuations in Narragansett Bay. Reviews in Fisheries Science 11(3): 221-242. doi: 10.1080/10641260390244413.

Raposa, K. B., and Weber, R. L. 2009. Establishing Salt marshes in the Narragansett Bay Research Reserve as reference marshes for long - term ecological monitoring. Technical Reports Series 2009:4. Narragansett Bay National Estuarine Research Reserve. http://nbnerr.org/wp-content/uploads/2016/12/2009RaposaWeber-NBNERR-Tech-Series-2009.4.pdf.

Rhode Island Department of Environmental Management (RI-DEM). 2010. DEM expands shellfish spawner sanctuaries for oyster restoration and adopts new regulations governing the harvest of Bay scallops. Providence, RI: Rhode Island Department of Environmental Management (RI-DEM). Accessed on 13 September 2018. http://www.dem.ri.gov/news/2010/pr/0927101.htm.

Rhode Island Department of Environmental Management (RI-DEM). 2016. 2016 shellfish sector management plan. Providence, RI: Rhode Island Department of Environmental Management (RI-DEM). www.dem.ri.gov/pubs/regs/regs/fishwild/mpshell.pdf.

Rhode Island Geographic Information System (RIGIS). n.d..Rhode Island maps and data. Kingstown, RI. The University of Rhode Island Environmental Data Center. http://www.rigis.org/.

Roman, C. T., K. B. Raposa, S. C. Adamowicz, M. J. James-Pirri, and J. C. Catena. 2002. Quantifying vegetation and nekton response to tidal restoration of a New England salt marsh. Restoration Ecology 1O(3): 450-460. https://doi.org/10.1046/i.1526-100X.2002.01036.x. 
Save the Bay: Narragansett Bay. n.d. Eelgrass Restoration. Providence, RI: Save the Bay Foundation. http://www.savebay.org/file/Eelgrass_Fact_Sheet_FINAL.pdf.

Save the Bay: Narragansett Bay. n.d. Salt marshes: A brief history. Providence, RI: Save the Bay Foundation. Accessed 13 September 2018. http://www.savebay.org/page.aspx?pid=2309.

Save the Bay: Narragansett Bay. 2013. Coastal erosion and adaptation on the Rhode Island Coastline. Providence, RI: Save the Bay Foundation. http://northeastoceancouncil.org/wp-content/uploads/2015/06/RIWhitePaper_CoastalErosion-and-Adaptation-on-the-RI-Coastline.pdf.

Schueler, T. R., L. Fraley-McNeal, and K. Cappiella. 2009. Is impervious cover still important? Review of recent research. Journal of Hydrologic Engineering 14(4): 309-315. https://doi.org/10.1061/(ASCE)1084-0699(2009)14:4(309).

Schwartz, M. L. 2009. Estuarine habitats of Narragansett Bay. An Ecological Profile of the Narragansett Bay National Estuarine Research Reserve. Chapter 8. Estuarine habitats of Narragansett Bay. http://nsgl.gso.uri.edu/riu/riut07001/Ch8.pdf.

Sheppard, J., and S. Block. 2013. Monitoring response of diadromous populations to fish passage improvements on a Massachusetts coastal stream. Journal of Environmental Science and Engineering A2:71-79. https://www.mass.gov/files/documents/2016/08/tr/contribution-41.pdf.

Smith, R. D., and C. V. Klimas. 2013. A multi-scale approach to assess and restore ecosystems in a watershed context. ERDC/EL-TR-13-18. Vicksburg, MS. Environmental Laboratory - Engineer Research and Development Center (ELERDC). http://hdl.handle.net/11681/6864.

Strahler, A. N. 1957. Quantitative analysis of watershed geomorphology. Eos. Transactions American Geophysical Union 38(6):913-920. https://doi.org/10.1029/TR038i006p00913.

Sundblad, G., U. Bergström, A. Sandström, and P. Eklöv. 2013. Nursery habitat availability limits adult stock sizes of predatory coastal fish. ICES Journal of Marine Science 71(3):672-680. https://doi.org/10.1093/icesjms/fst056.

University of Rhode Island. n.d. Green crab (Carcinus maenus). Adapted from The Uncommon Life on Narragansett Bay. Save the Bay Foundation. Accessed 13 September 2018. http://www.edc.uri.edu/restoration/html/gallery/invert/green.htm.

U.S. Army Corps of Engineers (USACE) Norfolk District. 2013. Final feasibility report and integrated environmental assessment. Appendices B-G, Lynnhaven River Basin Ecosystem Restoration. Norfolk, VA: USACE Norfolk District. http://www.nao.usace.army.mil/Portals/31/docs/civilworks/Lynnhaven/Lynnhaven_Appendix_ A.pdf.

U. S. Department of Agriculture - Natural Resources Conservation Service (USDANRCS). 2006. Final Watershed Plan - Areawide Environmental Impact Statement. Chapter 4 Watershed Problems and Opportunities. Washington, DC: Department of Agriculture. https://www.nrcs.usda.gov/Internet/FSE_DOCUMENTS/nrcs144p2_013659.pdf. 
U.S. Department of Agriculture - Natural Resources Conservation Service (USDA-NRCS) Rhode Island. 2011. Pawtuxet River restoration commemoration. Providence, RI: Natural Resources Conservation Service (USDA-NRCS) Rhode Island.News release. Accessed 18 September 2018. http://nbep.org/01/wpcontent/uploads/2015/06/Narragansett-Bay-Journal_Fall-2014_High-Resolution.pdf.

U.S. Geological Survey (USGS). 2018. Nonindigenous aquatic species database. Gainesville, FL: U.S. Geological Survey (USGS). Accessed 13 September 2018. http://nas.er.usgs.gov.

Waycott, M., C. M. Duarte, T. J. Carruthers, R. J. Orth, W. C. Dennison, S. Olyarnik, A. Calladine, J. W. Fourqurean, K. L. Heck, A. R. Hughes, and G. A. Kendrick. 2009. Accelerating loss of seagrasses across the globe threatens coastal ecosystems. In Proceedings of the National Academy of Sciences 106(30): 12377-12381.

West, J. 2014. What's going on with our salt marshes? And why should we care? Narragansett Bay Journal. Fall \#28. http://nbep.org/bayjournal-currentissue.html on 3 October 2016. 


\section{Appendix A: Project Information}

The table/spreadsheet found at http://dx.doi.org/10.21079/11681/29509 contains the project information collected for the analysis. 


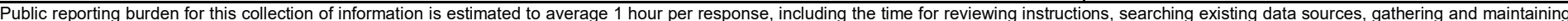

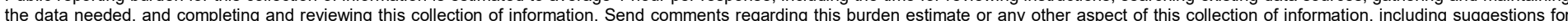

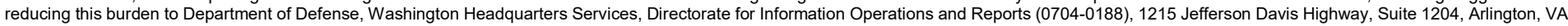

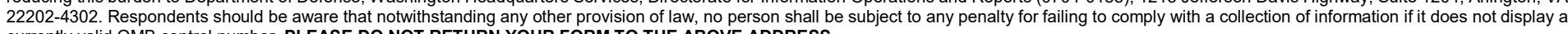
currently valid OMB control number. PLEASE DO NOT RETURN YOUR FORM TO THE ABOVE ADDRESS.
1. REPORT DATE (DD-MM-YYYY)
August 2018

\section{TITLE AND SUBTITLE}

Watershed Level Effects of Multiple Ecosystem Restoration Projects

\section{DATES COVERED (From - To)}

5a. CONTRACT NUMBER

5b. GRANT NUMBER

5c. PROGRAM ELEMENT NUMBER

5d. PROJECT NUMBER

5e. TASK NUMBER

5f. WORK UNIT NUMBER

468903

8. PERFORMING ORGANIZATION REPORT NUMBER

ERDC/EL TR-18-10

3909 Halls Ferry Road, Vicksburg, MS 39180-6199

\section{SPONSORING / MONITORING AGENCY NAME(S) AND ADDRESS(ES)}

Headquarters, U.S. Army Corps of Engineers

Washington, DC 20314-1000

10. SPONSOR/MONITOR'S ACRONYM(S)

(EMRRP)

11. SPONSOR/MONITOR'S REPORT NUMBER(S)

\section{DISTRIBUTION / AVAILABILITY STATEMENT}

Approved for public release; distribution unlimited.

\section{SUPPLEMENTARY NOTES}

\section{ABSTRACT}

This assessment in the Narragansett Bay demonstrates a transparent, defensible method to characterize ecosystem restoration projects in a watershed over large spatial scales. The project team compiled multiple completed projects in the Narragansett Bay watershed including salt marsh restorations, fish passage, and dam removals. The approach included the following: identifying and locating restoration projects, utilizing existing data resources for spatial information, quantifying the gains in area and distance, and extrapolating the potential for collective watershed benefit in fish populations, productivity, water quality and carbon sequestration. In total, 177 projects were identified as being implemented between 1999 and 2015: fish passage restoration (46), marsh restoration (35), eel grass restoration (22), shellfish restoration (43), and other projects (31). The collective efforts to improve fish passage have resulted in more than $800 \mathrm{~km}$ of newly accessible river herring habitat in the Narragansett Bay watershed.

15. SUBJECT TERMS
Watersheds

Restoration ecology

Restoration monitoring (Ecology)
Environmental management

Narragansett Bay Watershed (R.I.)

\section{SECURITY CLASSIFICATION OF:}

\begin{tabular}{|l|l|}
\hline a. REPORT & b. ABSTRACT \\
UNCLASSIFIED & UNCLASSIFIED
\end{tabular}

\section{c. THIS PAGE}

UNCLASSIFIED
17. LIMITATION OF ABSTRACT

\section{NUMBER OF PAGES}

70 19a. NAME OF RESPONSIBLE PERSON

19b. TELEPHONE NUMBER (include area code) 